MARCOS PETTO NUNES DE ABREU

\title{
PNEUMATIZAÇÃO DO TUBÉRCULO ARTICULAR DO OSSO TEMPORAL
}


Marcos Petto Nunes de Abreu

Pneumatização do tubérculo articular do osso temporal

Dissertação apresentada à Faculdade de Odontologia da Universidade de São Paulo, para obtenção do título de Mestre pelo Programa de Pós-Graduação em Odontologia.

Área de Concentração: Diagnóstico Bucal

Orientador: Prof. Dr. Cláudio Fróes de Freitas 
Catalogação-na-Publicação

Serviço de Documentação Odontológica

Faculdade de Odontologia da Universidade de São Paulo

Abreu, Marcos Petto Nunes de

Pneumatização do tubérculo articular do osso temporal / Marcos Petto Nunes de Abreu; orientador Cláudio Fróes de Freitas. -- São Paulo, 2007.

$65 p .:$ tab., fig., graf.; $30 \mathrm{~cm}$.

Dissertação (Mestrado - Programa de Pós-Graduação em Odontologia. Área de Concentração: Diagnóstico Bucal) -- Faculdade de Odontologia da Universidade de São Paulo.

$\begin{array}{lll}\text { 1. Radiografia panorâmica } & \text { 2. Osso temporal } \quad \text { 3. Articulação }\end{array}$ temporomandibular

CDD 616.0757

BLACK D622

AUTORIZO A REPRODUÇÃO E DIVULGAÇÃO TOTAL OU PARCIAL DESTE TRABALHO, POR QUALQUER MEIO CONVENCIONAL OU ELETRÔNICO, PARA FINS DE ESTUDO E PESQUISA, DESDE QUE CITADA A FONTE E COMUNICADO AO AUTOR A REFERÊNCIA DA CITAÇÃO.

São Paulo,

Assinatura:

E-mail: 
FOLHA DE APROVAÇÃO

Abreu MPN. Pneumatização do tubérculo articular do osso temporal [Dissertação de Mestrado]. São Paulo: Faculdade de Odontologia da USP; 2007.

São Paulo, / /

\section{Banca Examinadora}

1) $\operatorname{Prof}(a) \cdot \operatorname{Dr}(a)$

Titulação:

Julgamento:

Assinatura:

2) $\operatorname{Prof}(a) . \operatorname{Dr}(a)$.

Titulação:

Julgamento:

Assinatura:

3) $\operatorname{Prof}(a) . \operatorname{Dr}(a)$

Titulação:

Julgamento:

Assinatura: 


\section{DEDICATÓRIA ESPECIAL}

Dedico aos meus pais, Pedro e Maria da Penha, mais esta etapa como forma de recompensá-los por todos os sacrifícios e dedicação a minha criação. Dizer obrigado seria pouco para expressar a gratidão e o amor que tenho por vocês. 


\section{DEDICATÓRIA}

Aos meus irmãos, Silvio Antônio e Patricia, eternos amigos e cúmplices. Exemplos de dedicação e responsabilidade.

Aos meus cunhados, Cláudia e Rafael, que nos presentearam com suas qualidades.

Aos meus sobrinhos, João Pedro, Clara e Gabriel, que são motivos de muita alegria. 
"Se alguém quiser ser o primeiro, que seja o último de todos e aquele que serve a todos!" (Jesus em Marcos 9,35) 


\section{AGRADECIMENTO ESPECIAL}

Ao meu amigo e orientador, Prof. Dr. Cláudio Fróes de Freitas, agradeço imensamente sua mão estendida e seus valorosos ensinamentos, modelo profissional presente desde o início de minha vida acadêmica e profissional, o qual definitivamente deve ser seguido. Obrigado por acreditar em mim! 


\section{AGRADECIMENTO ESPECIAL}

À Profa. Dra. Marlene Soeiro de Matos Fenyo Pereira, minha incentivadora e colaboradora, desde a graduação, grande responsável pela minha dedicação a área de Radiologia. 


\section{AGRADECIMENTO ESPECIAL}

Ao Prof. Dr. Israel Chilvaquer, colaborador em meu aprendizado, que me apoiou e incentivou em diversos momentos. 


\section{AGRADECIMENTOS}

As companheiras da pós-graduação Elisabeth Mieko Shimura e Patrizia Moruzzi, minhas amáveis amigas pelo incentivo e ajuda em todos os momentos.

À secretária da disciplina de radiologia Maria Cecília Forte Muniz, pelo carinho e disponibilidade.

À todos os professores e colegas da Disciplina de Radiologia, por me ajudarem a sempre melhorar.

À funcionária do Hospital Universitário Janete Passos Santana pela solicitude em todos estes anos de monitoria, estágio, especialização e pós-graduação.

Aos meus pacientes, razão de eu querer ser sempre um melhor profissional 
Abreu MPN. Pneumatização do tubérculo articular do osso temporal [Dissertação de Mestrado]. São Paulo: Faculdade de Odontologia da USP; 2007.

\section{RESUMO}

A pneumatização do tubérculo articular do osso temporal (PTA) é uma variação anatômica, observada radiograficamente como uma área radiolúcida uni ou multilocular, similar às observadas nas células aéreas do processo mastóide do osso temporal, não expansiva ou destrutiva, e não se estendendo além da sutura zigomático-temporal. No presente trabalho nos propusemos a conhecer, por meio do levantamento epidemiológico de 3823 radiografias panorâmicas, a incidência e as características da PTA em pacientes atendidos pelo Serviço de Radiologia da Clínica de Odontologia da Faculdade de Odontologia da Universidade de São Paulo. A PTA foi encontrada em 68 pacientes $(1,78 \%)$ com idade cronológica média de 40 anos $( \pm 20,85)$ em intervalo etário de 8 a 87 anos; sendo que destes casos, $39(57,4 \%)$ ocorreram no gênero feminino e 29 (42,6\%) no gênero masculino. A PTA ocorreu unilateralmente em 42 casos $(61,8 \%)$ e bilateralmente em 26 casos $(38,2 \%)$. Radiograficamente 42 (44,6\%) eram de padrão unilocular e 52 (55,4\%) de padrão multilocular. O reconhecimento da PTA é de suma importância para se evitar interpretações incorretas com afecções e avaliar sua influência na evolução de processos sépticos, na reparação tecidual e no planejamento cirúrgico na região da articulação têmporo-mandibular.

Palavras-Chave: radiografia panorâmica, osso temporal, articulação têmporomandibular, pneumatização do tubérculo articular do osso temporal, Radiologia Odontológica 
Abreu MPN. Temporal bone pneumatized articular tubercule [Dissertação de Mestrado]. São Paulo: Faculdade de Odontologia da USP; 2007.

\section{ABSTRACT}

The temporal bone pneumatized articular tubercule (PAT) is a anatomical variant, seen on radiographs as a unilocular or multilocular radiolucency, similar to those in mastoid process, noexpansile or nondestructive, and do not extend beyond the zygomatictemporal suture. The purpose of this study was to know, by a epidemilogical analysis of 3823 panoramic radiographs, the incidence and characteristics of the PAT, in dental patients from the Dental Clinic, at the Radiology service in University of São Paulo. The PAT was found in 68 patients $(1,78 \%)$ with mean cronological age of 40 years $( \pm 20,85)$ with a range of 8 to 87 years; while 39 $(57,4 \%)$ occured in females and $29(42,6 \%)$ in male. Unilateral PAT was found in 42 cases $(44,6 \%)$ and bilateral in 26 cases (38,2\%). Radiography aspects showed 42 cases $(44,6 \%)$ as unilocular and 52 cases $(55,4 \%)$ as multilocular. The knowledge of the PAT is very important to avoid misdiagnosis within other diases ocorring in the area, and avaliate her influency in the evolution of septic process, realing process, and at the cirurgical management of the temporomandibular joint.

Keywords: panoramic radiography, temporal bone, temporomandibular joint, pneumatized articular tubercule, dental radiography 


\section{LISTA DE ABREVIATURAS E SÍMBOLOS}

FOUSP - Faculdade de Odontologia da Universidade de São Paulo $\mathrm{kVp}$ - quilovoltagem pico

$\mathrm{mA}$ - miliamperagem

cm - centímetro

$\mathrm{cm}^{2}$ - centímetro quadrado

$\mathrm{cm}^{3}$ - centímetro cúbico

PTA - pneumatização do tubérculo articular do osso temporal

PAT - temporal bone pneumatized articular tubercule

ZACD - zygomatic air cells defect 


\section{SUMÁRIO}

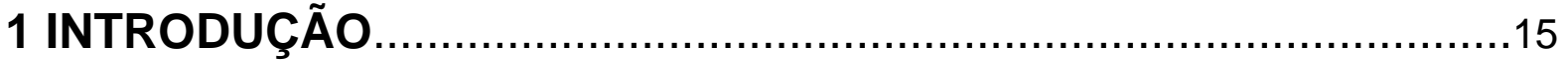

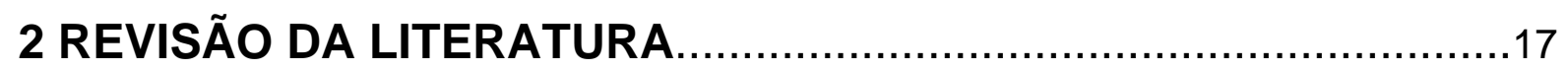

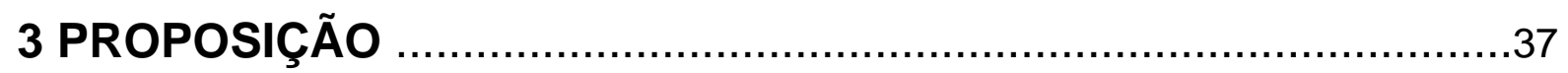

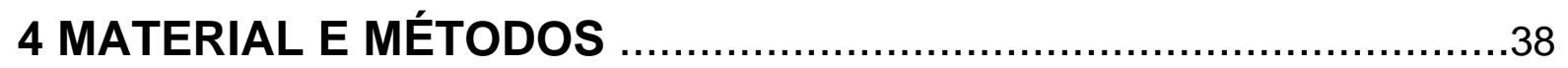

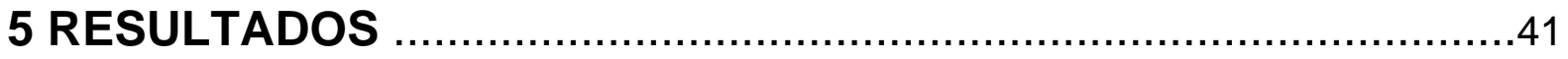

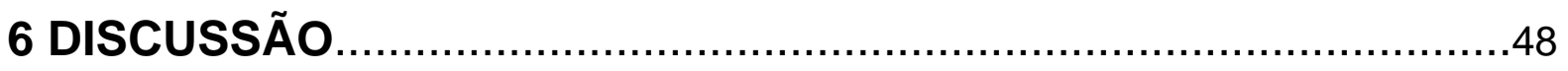

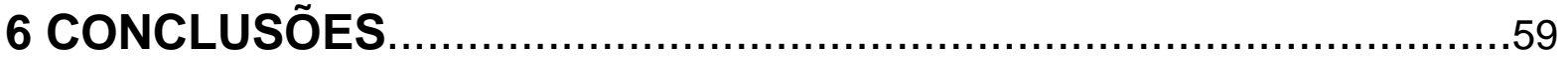

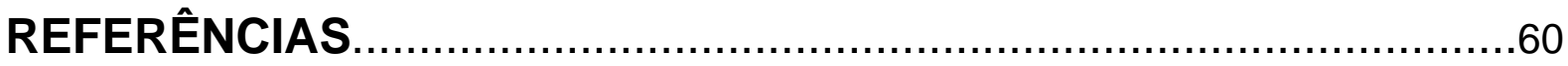

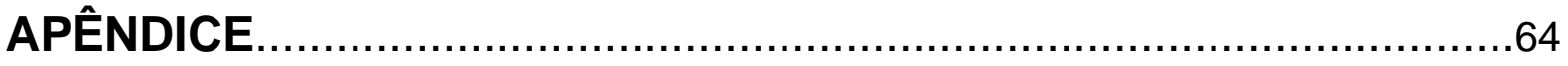

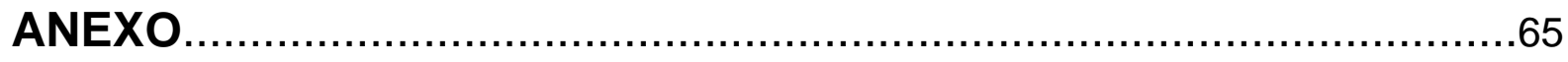




\section{INTRODUÇÃO}

O diagnóstico de uma doença segue alguns passos como a ananmese, o exame físico ou clínico e os exames complementares. Os exames imaginológicos, na modalidade de exame complementar, já estão consagrados e são amplamente utilizados.

Muitas vezes quando da realização de radiografias, deparamo-nos com os chamados achados radiográficos, que podem ser alterações patológicas, que até o momento não se tinha conhecimento (pois o paciente não apresentava sinais ou sintomas); ou variações anatômicas.

As variações anatômicas são diferenças morfológicas, dentro da normalidade, apresentadas por uma parcela da população, que por si só não causam ou se caracterizam por serem afecções.

O reconhecimento destas variações anatômicas é de suma importância, para poder diferenciá-las das afecções, e definir se a sua presença influenciaria no processo de saúde-doença, predispondo o indivíduo a alguma condição debilitante, ou seja interferindo no tratamento proposto para uma enfermidade, ou na sua evolução.

A pneumatização se refere ao desenvolvimento de cavidades intra-ósseas, com ar em seu interior. O maior exemplo destas pneumatizações são os seios paranasais, somando-se a estes, as células aéreas acessórias, as quais podem ocorrer em inúmeros locais do crânio, em particular no osso temporal. (KOWALIK,1967) 
No osso temporal, a pneumatização começa com a formação de pequenas cavidades aéreas, resultantes de uma atividade periosteal normal. Divididas em três estágios: infantil (do nascimento aos 2 anos de idade cronológica), onde as células aéreas se iniciam no antro mastoídeo; transitório (de 2 aos 5 anos de idade cronológica), momento onde ocorre o desenvolvimento gradual da porção escamosa do osso temporal, com a migração das células aéreas para a periferia; e adulto, o estágio final que a pneumatização se completa, geralmente no final da puberdade, as células aéreas ficam mais evidentes radiograficamente devido a calcificação das suas paredes. (SHAPIRO,1981).

A pneumatização e o arranjo destas células aéreas podem variar muito, desde uma pequena célula até o envolvimento de grande parte do osso temporal, divididas em pneumatização mastoídea, pneumatização petrosa e pneumatização acessória, a qual se estendenderia além dos limites das regiões mastoídea e petrosa. (ALLAM, 1969)

Por vezes, as pneumatizações acessórias atingem regiões mais distantes como o tubérculo articular do osso temporal, podendo causar confusões ao mimetizar em radiografias doenças na região. (VIRAPONGSE et al.,1995)

A pneumatização do tubérculo articular do osso temporal (PTA) é geralmente detectada em exames radiográficos de rotina, particularmente por meio da radiografia panorâmica, sendo necessário o seu reconhecimento como uma variação anatômica. (DELUKE, 1995; HASNAINI, 2000; KAUGARS; MERCURI; LASKIN, 1986; KULIKOWSKI; SCHOW; KRAUT, 1982; PIETTE, 1986; RANDZIO et al., 1989; ROSER; RUDIN; BRADY, 1976; SANDERS; FREY; MCREYNOLDS, 1978; STOOPLER et al., 2003; TYDALL; MATTERSON, 1987; YUROSKO, 1985;). 


\section{REVISÃO DA LITERATURA}

Kowalik (1967) discutiu a respeito da anatomia do osso temporal, demonstrando as dimensões e a relação das articulações têmporo-mandibulares com as estruturas anatômicas vizinhas. $\mathrm{O}$ autor descreveu a presença de pequenas cavidades ósseas, preenchidas por ar, principalmente na região do processo mastóide, as chamadas células aéreas ou mastoídeas. O artigo identificou as diversas atribuições, existentes na literatura, a respeito das células mastoídeas, as quais incluíam a recepção do som, a ressonância da voz, como isolante térmico e acústico, reservatório aéreo, proteção contra traumas auditivos externos e diminuição do peso do crânio.

Allam (1969) publicou um artigo a respeito da pneumatização do osso temporal, discutindo as suas implicações anatômicas e a influência na evolução de processos infecciosos e fraturas, presentes nesta região. Segundo o autor o termo pneumatização se referia ao desenvolvimento de cavidades ósseas aéreas no tecido ósseo, que juntamente com os seios paranasais ocorriam em vários locais do crânio. Descreveu que a pneumatização do osso temporal ocorria em 5 regiões primárias: ouvido médio, perilabiríntica, ápice da porção petrosa, escamomastoídea e acessória (estendendo-se além dos limites da região mastoídea e petrosa). A pneumatização se iniciava com a formação de pequenas cavidades ósseas, criadas a partir de atividade periosteal normal. A medula óssea primitiva presente nestas cavidades se diferenciava em tecido conjuntivo mesenquimal frouxo. Com a invaginação epitelial no tecido conjuntivo, surgia uma membrana mucosa, que em sua evolução se atrofiava, resultando em uma membrana de revestimento fina e 
residual aderida ao periósteo. Com o passar do tempo, o remodelamento e a reabsorção óssea subepitelial ocorriam, levando a expansão das células aéreas.

Stricker (1970), demonstrou a influência das pneumatizações do osso temporal na evolução de processos sépticos na região, e sua importância na reparação tecidual. Em seu estudo, o autor comparou a evolução e a terapêutica em casos de mastoidites provenientes de otites médias na infância. Como resultado, observou que crianças que possuíam maior pneumatização na área do processo mastóide, apresentavam infecções mais complexas e refratárias, e a reparação após a mastoidectomia era mais difícil.

Roser, Rudin e Brady (1976) realizaram o primeiro relato de caso a respeito de uma grande "célula aérea mastoídea periférica", encontrada no arco zigomático de uma paciente com 19 anos de idade cronológica, e portadora de disfunção têmporo-mandibular, a qual realizou exames radiográficos para o tratamento clínico.

Sanders, Frey e Mcreynolds (1978) publicaram um artigo a respeito das avaliações anatômica, radiográfica e clínica; em pacientes portadores de deslocamentos recorrentes e de subluxação crônica, tratados com a redução do tubérculo articular. Os autores relataram que em 3 pacientes $(0,1 \%)$ da série de 3000 radiografias panorâmicas, que foram examinadas para os parâmetros do estudo, foi observada uma pneumatização significante no arco zigomático. Os autores não descreveram as características desta pneumatização, nem as da população estudada, mas afirmaram que a exposição de grandes pneumatizações, durante as cirurgias de redução do tubérculo articular, poderiam potencialmente servir de via de acesso para infecções cranianas. Os autores concluíram que o planejamento e a avaliação imaginológica pré-operatória da região era muito 
importante, e caso fosse detectada a pneumatização no tubérculo articular, seria prudente realizar uma técnica cirúrgica alternativa para a redução.

Shapiro (1981) discorreu a respeito dos padrões radiográficos do crânio humano normal. A pneumatização do osso temporal poderia ser dividida em 3 estágios: infantil (do nascimento aos 2 anos de idade cronológica), transitório (de 2 a 5 anos de idade cronológica) e adulto. No estágio infantil, o processo mastóide (escamomastóide) sofria crescimento gradual, com as células aéreas começando a surgir no antro mastoídeo. No estágio transitório, o processo escamomastoídeo seguia seu crescimento, com migração das células aéreas para a periferia. A pneumatização se completaria no estágio adulto, geralmente com o término da puberdade; onde devido a expansão e a calcificação de suas paredes, as células aéreas ficavam mais evidentes radiograficamente.

Kulikowski, Schow e Kraut (1982) descreveram um caso de um paciente de 19 anos de idade cronológica, que possuía deslocamento crônico da cabeça da mandíbula, no qual descobriram células aéreas no tubérculo articular do osso temporal, quando da realização da cirurgia para a redução de fratura neste tubérculo. A importância da detecção, dessa variação anatômica foi discutida, bem como sua influência na técnica cirúrgica empregada.

Lindeman e Haglund (1983) apresentaram um estudo sobre a variação da amplitude do sistema de células aéreas mastoídeas, quando medidas e comparadas em radiografias laterais da articulação têmporo-mandibular, e por meio de radiografias realizadas em um novo aparelho de raios-X de princípio panorâmico (Orbix), com movimento isocêntrico entre o cabeçote de raios-X e o filme radiográfico. Não foram encontradas diferenças estatisticamente significantes, entre as medidas obtidas por meio das imagens, referentes as duas técnicas; sendo que 
ambas poderiam ser utilizadas para se avaliar o grau de pneumatização e o planejamento cirúrgico na região. Entretanto as imagens das células aéreas eram mais evidentes através do uso da radiografia panorâmica, devido a menor sobreposição de estruturas anatômicas a região radiografada.

Em 1984, Sewerin, Rosenkilde e Andersen advertiram em seu estudo, que as pneumatizações no tubérculo articular do osso temporal possuíam como padrão radiográfico a presença de uma imagem radiolúcida, de limites definidos uni ou multilocular. Este padrão poderia mimetizar lesões císticas, quando observadas em radiografias panorâmicas, apontando a importância da correta interpretação desta variação morfológica.

Nager e Holliday (1984) descreveram as características da displasia fibrosa no osso temporal. Segundo os autores, normalmente a displasia fibrosa quando ocorria nos ossos do crânio, afetava especialmente os ossos esfenóide e frontal, seguido pelo o etmóide e os ossos parietais. Salientaram que de rara ocorrência, quando o osso temporal era envolvido na doença, normalmente todo o osso acabava sendo comprometido. Os sintomas mais comuns da displasia fibrosa em osso temporal eram a perda progressiva da audição, aumento de volume gradual e perda do contorno do osso temporal. Os padrões radiográficos variavam de acordo com o grau de maturação da lesão; no estágio inicial se apresentavam radiolúcidas e a medida que iriam sofrendo mineralizações, com o aumento da densidade óssea, freqüentemente o padrão radiográfico se tornava de "vidro despolido", "casca de laranja" ou padrão de "impressão digital".

Yurosko (1985) relatou o caso clínico de uma paciente, do gênero feminino, de 18 anos de idade cronológica, com pneumatização do tubérculo articular de ambas as articulações têmporo-mandibulares, as quais foram encontradas em 
exame radiográfico panorâmico para o planejamento odontológico clínico; e précirúrgico da exodontia dos quatro terceiros molares. O autor concluiu em seu relato, a importância de se reconhecer esta variação morfológica, a qual poderia ser confundida com algum processo patológico.

Tydall e Matterson (1985) afirmaram que a pneumatização do tubérculo articular do osso temporal, era uma cavidade similar àquela vista no processo mastóide e osso etmóide. Na interpretação de 1061 radiografias panorâmicas, de pacientes com idade cronológica média de 32.5 anos, com intervalo etário de 15 a 74 anos, observaram a incidência desta pneumatização em 28 pacientes (2,6\%), sem predileção por gênero; sendo que 5 pacientes a apresentavam bilateralmente. Dois padrões radiográficos foram observados, unilocular em 17 casos $(53,1 \%)$ e multilocular em 15 casos (46,9\%). Estes aspectos radiográficos poderiam aparentar a presença de doenças na região, tais como um cisto ósseo aneurismático, hemangiomas ou até mesmo tumores ósseos metastáticos. Os autores concluíram que a radiografia panorâmica era um método eficaz e importante na sua detecção, e principalmente no planejamento cirúrgico do tubérculo articular do osso temporal. A radiografia panorâmica era a técnica radiográfica de eleição, para se observar a região posterior do arco zigomático; sendo que, as radiografias convencionais, representadas pelas: técnica póstero-anterior para seios maxilares, de Towne, submento vértex e ainda a transcraniana não possibilitavam uma boa imagem para a verificação das pneumatizações.

Piette (1986) discutiu em seu artigo, a pneumatização do tubérculo articular do osso temporal, afirmando que se tratava de um achado radiográfico, sem sinais clínicos, sendo uma imagem radiolúcida uni ou multilocular; geralmente unilateral, afetando ambos os gêneros. O uso rotineiro da radiografia panorâmica promoveria 
um aumento no número de achados, e que embora não necessitasse de qualquer tratamento, estes defeitos poderiam complicar intervenções cirúrgicas nas articulações têmporo-mandibulares.

Kaugars, Mercuri e Laskin (1986) mostraram a incidência e o desenvolvimento da pneumatização do tubérculo articular do osso temporal e sua importância em tratamentos cirúrgicos nas articulações têmporo-mandibulares. Por meio da interpretação de 784 radiografias panorâmicas, detectaram sinais da pneumatização em 8 (1\%) radiografias; sendo que a idade cronológica média destes pacientes foi de 45,9 anos, variando de 32 a 69 anos. Nestes casos, 4 eram unilaterais e 4 bilaterais. Quanto a classificação das pneumatizações, argumentaram que devido a sobreposição radiográfica e a falta de relevância e aplicabilidades clínicas, a classificação quanto ao padrão radiográfico era desnecessária e não se justificaria. Os autores mostraram que a radiografia panorâmica era útil na detecção da presença da pneumatização, mas recomendaram o uso do método tomográfico previamente a realização de qualquer procedimento cirúrgico, o qual envolvia o tubérculo articular, para se determinar sua extensão e real relacionamento com as áreas anatômicas adjacentes, para um correto planejamento cirúrgico. Quanto a técnica cirúrgica na existência da pneumatização, deveria ser cuidadosa no uso dos instrumentos denominados osteótomos e cinzéis, a fim de se evitar uma penetração intempestiva neste espaço aéreo. No caso do comprometimento da membrana dural e extravasamento de líquido cérebro-espinal, seria possível usar enxerto muscular ou da fáscia do músculo temporal; e para o defeito ósseo provocado, o uso de metilmetacrilato ou enxerto ósseo autógeno seria útil para sua obliteração. Desta maneira, os autores afirmaram ser de suma importância o correto planejamento de 
cirurgias em articulações têmporo-mandibulares, principalmente naquelas em que se detectarem pneumatizações, para evitar acidentes transoperatórios e complicações.

O termo "zygomatic air cells defect" (ZACD) foi introduzido por Tydall e Matterson (1987), para descrever as PTA, células acessórias, que ocorriam na origem do arco zigomático ou no tubérculo articular do osso temporal; e que eram observadas em radiografias panorâmicas. Descreveram os padrões radiográficos unilocular, como uma cavidade solitária; e os padrões multilocular ou trabecular, pequenas células aéreas separadas por septos ósseos, com aparência de favo de mel. Como as principais características das PTA, os autores descreveram, 1- defeito radiolúcido assintomático no processo zigomático do osso temporal, de aparência similar ao das células aéreas mastoídeas, 2- a extensão anterior do defeito atingiria até a tubérculo articular, mas não ultrapassaria a sutura zigomático-temporal, e 3ausência de expansão óssea ou destruição da cortical. Tais características eram para se fazer diagnóstico diferencial com afecções, como o cisto ósseo aneurismático, lesão central de células gigantes, hemangioma, granuloma eusinófilo, displasia fibrosa e tumores metastáticos.

Dietzel (1989) investigou e descreveu a pneumatização do osso temporal por meio de radiografias da região; onde determinou o padrão de normalidade da pneumatização deste osso, principalmente em seu processo mastóide, local do qual as pneumatizações acessórias normalmente surgiam. Em seus resultados, demostrou que estas pneumatizações seguiam uma curva normal, com áreas variando no mínimo de $4 \mathrm{~cm}^{2}$, sendo a média de $8-12 \mathrm{~cm}^{2}$ e com valores máximos em $26 \mathrm{~cm}^{2}$.

Randzio et al. (1989) reportaram um caso de pneumatização do tubérculo articular do osso temporal. Os autores concluíram que esta variante anatômica, 
geralmente um achado radiográfico, sem implicações patológicas, deveria ser detectada previamente a procedimentos cirúrgicos na região, pois poderia influenciar na técnica cirúrgica, na evolução de processos sépticos e na reparação tecidual.

Hadjigeorgi et al. (1990) discutiram o envolvimento do osso temporal pelo granuloma eusinófilo, por meio da apresentação de 6 casos. Segundo os autores o granuloma eusinófilo era uma das três variantes da histiocitose $\mathrm{X}$, relativamente rara e inicialmente assintomática. O quadro clínico geralmente evoluía de erosão na cortical do processo mastóide, para destruição do osso e tecidos moles, com posterior erosão dos canais semicirculares e da cóclea. A lesão típica aparecia como um pólipo auricular ou aumento de volume pós-auricular com otorréia crônica. O padrão radiográfico geralmente se caracterizava por uma radiolucência bem delimitada, expansiva e destrutiva; presente na diploe óssea afetando preferencialmente a tábua óssea externa. Os autores alertaram que esta lesão era freqüentemente confundida com doenças infeciosas ou condições neoplásicas do osso temporal.

Deluke (1995) publicou o relato de caso, referente a uma mulher de 16 anos de idade cronológica, com dor muscular; que por meio da radiografia panorâmica, observou-se uma área radiolúcida multilocular, na região do tubérculo articular do osso temporal; lado esquerdo. Exames de tomografia computadorizada e ressonância magnética foram realizados para se confirmar a interpretação de extensa pneumatização da área. Esse tipo de pneumatização estaria presente de 0,1 a $1 \%$ da população, e que ocorria bilateralmente em $50 \%$ dos casos. O autor chamou a atenção para os tumores multiloculares, os quais podiam afetar o osso temporal e que faziam diagnóstico diferencial com as pneumatizações do tubérculo articular, tais como: lesão central de células gigantes, mixoma, cisto ósseo 
aneurismático, hemangioma, granuloma eusinófilo, displasia fibrosa e tumores metastáticos. Entretanto apenas as PTA acometiam o arco zigomático, sem a presença de sintomatologia, expansão ou destruição das corticais; sendo detectáveis por meio do exame radiográfico.

Page e Peters (1995) apresentaram um caso de cisto ósseo aneurismático ocorrendo no arco zigomático. Os autores ressaltaram o conceito de que o cisto ósseo aneurismático era uma lesão vascular rara, a qual ocorria mais comumente nos ossos longos, sendo de ocorrência mais rara ainda na região de cabeça e pescoço. Em revisão da literatura, encontraram apenas dois casos descritos, ocorrendo arco zigomático. Os autores discutiram as modalidades de tratamento para esta doença, sendo que indicaram o tratamento de embolização arterial seletiva e completa excisão da região afetada.

Virapongse et al. (1995) em artigo a respeito da pneumatização do osso temporal demostraram seu padrão e morfologia por meio da tomografia computadorizada. Os autores afirmaram que a região escamomastoídea estava comprometida com a pneumatização das duas principais regiões, o antro mastoídeo e a área periantral. As células aéreas periantrais localizadas superiormente ao processo mastóide, poderiam migrar para a porção escamosa do osso temporal, podendo até se estender para o arco zigomático. $\mathrm{O}$ desenvolvimento da pneumatização do processo mastóide estaria quase completo por volta dos 5 anos de idade cronológica, mas as células aéreas continuariam seu crescimento ao longo da vida adulta. Os autores consideraram de extrema importância o reconhecimento da pneumatização do osso temporal, para que não houvesse confusões com doenças, e na presença desta adequar a técnica preconizada, em tratamentos cirúrgicos na região; e esperar dificuldades no processo de reparação e no 
tratamento de processo infecciosos. Afirmaram que a radiografia panorâmica era válida para se detectar as pneumatizações do osso temporal, mas elegeram a tomografia computadorizada como o melhor método de estudo para a avaliação das estruturas ósseas e espaços aéreos situados na base do crânio.

Streitmann e Sismanis (1996) estudaram os carcinomas metastáticos do osso temporal, fazendo uma revisão da literatura, onde encontraram 212 casos descritos. As conclusões desta análise foram de que os carcinomas metastáticos no osso temporal, geralmente eram originados de câncer primários dos seguintes locais, por ordem de freqüência: mama, pulmão, faringe, rim e próstata. A ocorrência de metástases nesta região era relativamente rara, e freqüentemente não eram detectadas, por serem assintomáticas na fase inicial ou por ficarem desapercebidas por outras metástases mais debilitantes, presentes em outras partes do corpo. Existiam três vias para o acometimento do osso temporal, proveniente do câncer primário: 1- disseminação hematogênica, 2- expansão direta de tumores adjacentes, e 3- carcinomatose leptomeningeana metastática difusa. Na maioria dos casos, o aparecimento de sintomas em osso temporal era tardio, mas em alguns casos sintomas otológicos eram um sinal inicial do tumor, particularmente nos casos de disseminação leptomeningeana.

Savastano, Russo e Dell'aquila (1997), fizeram um relato de caso e uma revisão da literatura sobre um hemangioma ósseo no osso zigomático. Afirmaram que o hemangioma ósseo era uma lesão rara, com incidência de 0,5 a 1,0\% de todas as neoplasias ósseas. Aparentemente apresentaria uma predileção pela coluna vertebral, calvária e ossos longos. Segundo os autores, o hemangioma ósseo envolvendo o osso zigomático era raro com apenas 22 casos descritos na literatura, sendo que a maioria se apresentava como um aumento de volume, duro à palpação, 
na região infra-orbital, nenhum presente na região do arco zigomático. Clinicamente tinha como características: o aumento de volume, com sintomatologia dolorosa na região, de crescimento gradual e contínuo; e o deslocamento superior do globo ocular. Radiograficamente se apresentaria como uma radiolucência uni ou multilocular, de padrão "favo de mel", expansiva, que freqüentemente continha múltiplas espículas ósseas ou denominado padrão de "raios de sol".

Carter et al. (1999) demostraram em seu estudo, a incidência e as características da pneumatização do tubérculo articular do osso temporal. Esta foi definida como sendo uma radiolucência, não expansiva, não destrutiva, de aparência cística, presente no arco zigomático, similar às células aéreas mastoídeas, e que não se estendia além da sutura zigomático-temporal. As PTA seriam provenientes da extensão das células aéreas do antro mastoídeo para periferia, nas regiões do processo zigomático e tubérculo articular do osso temporal (figura 2.1).

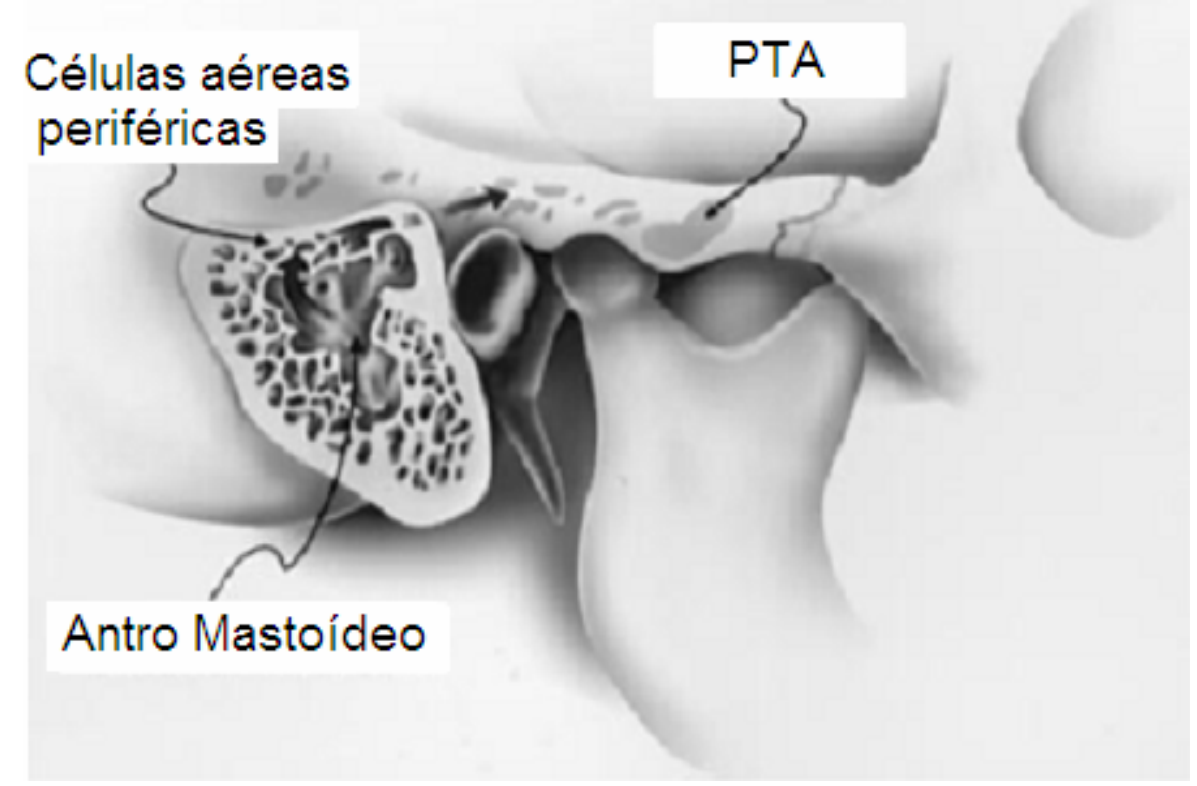

Figura 2.1 - Representação da ocorrência das células aéreas mastoídeas do osso temporal no processo zigomático e no tubérculo articular, provenientes do antro mastoídeo e das células aéras periféricas Carter et al. (1999) 
No exame de 2734 radiografias panorâmicas, 40 pacientes (1.5\%) apresentaram a pneumatização, estes possuíam idade cronológica média de 49.6 anos, com intervalo etário de 17 a 83 anos, sendo a incidência por igual em cada gênero. Em 32 (60\%) casos a pneumatização era unilateral, sendo 17 situadas no lado direito e 15 no lado esquerdo; enquanto em 8 (20\%) era bilateral. Estes resultados foram comparados aos da literatura, através de meta-análise, na qual se constatou, que em 4579 pacientes, incluindo a amostra dos autores; 76 (1,7\%) apresentaram o tubérculo articular pneumatizado, com intervalo etário de 15 a 83 anos; sendo que $34(44,7 \%)$ ocorrendo em homens e $42(55,3 \%)$ em mulheres. A ocorrência bilateral foi observada em 17 (22,4\%) dos pacientes. Concluíram que esta pneumatização era uma variante anatômica, não muito rara, e que cirurgiões, que planejavam reduções no tubérculo articular ou outros procedimentos cirúrgicos envolvendo o arco zigomático, deveriam estar atentos a esta variação morfológica, fazendo o planejamento e estudo imaginológico prévios, evitando-se complicações e a necessidade de reconstruções intra-operatórias.

Os autores concordaram que classificar a PTA era especulativo, baseandose somente no tipo de trabeculado ósseo observado na imagem radiográfica e também o número de relatos de casos, até aquele momento era considerado pequeno. Era sim de grande importância o reconhecimento, para diferenciá-la de outras condições debilitantes. Apenas a pneumatização do tubérculo articular ocorria no arco zigomático com alguma freqüência e se apresentava como uma radiolucência assintomática, não expansiva, não destrutiva, detectada em radiografias panorâmicas. Todas as outras condições no diagnóstico diferencial seriam caracterizadas pela presença de uma massa ou edema na região zigomática, freqüentemente associada a dor, assimetria facial, abaulamento ósseo com 
destruição da cortical e padrões radiográficos mistos, com a presença de pequenos focos ou espículas.

Groell e Fleischmann (1999) executaram um trabalho, com o uso da tomografia computadorizada, de alta resolução, para compreender o relacionamento topográfico entre os espaços aéreos do osso temporal com a articulação têmporomandibular. Em seus resultados, demonstraram que a pneumatização variou consideravelmente. No estudo de 100 tomografias computadorizadas, observaram a presença de pneumatização em 51 casos, localizada no teto da fossa mandibular, 12 no tubérculo articular do osso temporal e 5 no processo zigomático da maxila. Concluíram que a pneumatização do osso temporal freqüentemente se estendia em áreas próximas a articulação, e que o conhecimento desta era primordial para a correta interpretação das imagens da região, bem como na evolução de doenças articulares. Concordavam que as pneumatizações do tubérculo articular podiam ser estudadas, por meio de incidências panorâmicas, mas que células aéreas superficiais só poderiam ser constatadas, por meio de tomografias de alta resolução.

A pneumatização excessiva do osso temporal foi descrita por Wong e Munk (1999), como uma preocupação quando da realização da interpretação de afecções presentes nas articulações têmporo-mandibulares. Os autores observaram que áreas de hiposinal surgiam no osso temporal, recobrindo a fossa mandibular, em seqüências de densidade protônica quando realizada a ressonância magnética; tal achado poderia simular a presença de um crescimento tecidual. Nestas situações, a tomografia computadorizada mostrava uma extensa pneumatização das células aéreas mastoídeas para esta região. Por meio da revisão de 12 casos de pacientes, os quais realizaram a ressonância magnética e a tomografia computadorizada das articulações têmporo-mandibulares, demonstraram haver forte correlação da 
presença da imagem de hiposinal da ressonância com o grau da pneumatização observada na tomografia. Como conclusão, os autores estabeleceram que o reconhecimento da presença de uma imagem de hiposinal recobrindo a fossa mandibular, poderia por vezes se tratar de um pneumatização extensa das células aéreas mastoídeas, evitando que estas fossem confundidas com imagens compatíveis com lesões fibrosas ou ósseas.

Hasnaini (2000) descreveu o caso clínico de uma paciente de 18 anos de idade cronológica, portadora de disfunção articular. Na radiografia panorâmica foi observada a presença de uma leve erosão das cabeças da mandíbula, e o achado radiográfico de radiolucências multiloculares em ambos os arcos zigomáticos. Com a realização da tomografia computadorizada, foi possível observar extensas pneumatizações dos ossos temporais. Esta descrição, segundo os autores, reforçou a importância de se diferenciar essas pneumatizações do osso temporal, uma vez que como no caso descrito, quando em grande volume e aparência multilocular, poderiam mimetizar alguma lesão.

Moore et al. (2001) realizaram o relato do caso de hemangioma intra-ósseo localizado no osso zigomático, analisando os padrões imaginológicos por meio da tomografia computadorizada e da ressonância magnética. Afirmaram que esta condição era incomum, constituindo apenas 1\% de todos os tumores ósseos; sendo que os locais de predileção eram a calvária e a coluna vertebral. O envolvimento dos ossos da face era raro, podendo ocorrer em maxila, mandíbula e ossos nasais. Em sua revisão de literatura, encontraram 20 casos de hemangioma intra-ósseo, com comprometimento do osso zigomático. Concluíram que o padrão imaginológico, observado nos cortes axiais, freqüentemente era bem característico com a presença de um trabeculado ósseo irradiado e intacto, com corticais adelgaçadas. 
Hofmann et al. (2001) demostraram a incidência da PTA em 1,85\%, de uma série de 1084 radiografias, a exemplo da literatura, a idade cronológica média destes 20 pacientes, foi de 43,2 anos $( \pm 18,4)$ e intervalo etário de 7 a 87 anos. Sem predileção por gênero, 11 (55\%) casos eram em mulheres e 9 (45\%) casos eram em homens, foi encontrada bilateralmente em 4 pacientes (20\%). Os autores consideraram a importância de se documentar um caso, em uma criança de 7 anos de idade cronológica, já que se considerava que a pneumatização do arco zigomático, ocorria após a puberdade; e nenhum outro caso similar havia sido descrito. Este achado podia ser relevante em pacientes jovens, em tratamento de otites médias ou mastoidites.

Yetiser, Karahatay e Deveci (2002) apresentaram um caso bilateral de granuloma eusinófilo nos ossos temporais de um menino de 2 anos de idade cronológica; e realizaram uma revisão da literatura. Os autores demostraram que na literatura o granuloma eusinófilo, juntamente com a forma Letterer-Siewe e a forma Hand-Schuller-Christian, era uma das três variantes de uma doença que envolvia o sistema retículo-endotelial, conhecida como histiocitose $X$. Normalmente 0 granuloma eusinófilo era caracterizado por lesões ósseas líticas únicas ou múltiplas, causadas por hiperplasia difusa de células de Langerhans ou disfunção dos linfócitos T supressores. O quadro comum se tratava de um granuloma inflamatório destrutivo do esqueleto, tecido mole adjacente e órgãos. Freqüentemente ocorria em ossos planos como: costelas, pélvis, escápula e o crânio; o envolvimento do osso temporal era raro com 30 casos descritos, sendo que nenhum deles afetava o arco zigomático. O padrão radiográfico geralmente se caracterizava por uma radiolucência bem delimitada, expansiva e destrutiva; presente na diploe óssea e afetava preferencialmente a cortical óssea externa. 
Koc et al. (2003) demostraram uma técnica, para avaliação do volume das células aéreas mastoídeas, por meio do uso da tomografia computadorizada multiplanar, em terceira dimensão. Segundo os autores, a cavidade mastoídea não era apenas um reservatório de ar, mas também um espaço ativo nas trocas gasosas e de grande importância na patofisiologia das doenças inflamatórias do ouvido médio. Neste estudo foi avaliada a pneumatização de 100 ossos temporais normais, onde foram mensurados os volumes das células aéreas. Como resultado obtiveram $7,9 \mathrm{~cm}^{3}$ de volume médio, dividindo a amostra em três grupos: $28 \%$ com pequena pneumatização, a qual não excedia $6 \mathrm{~cm}^{3}, 52 \%$ com pneumatização média entre $6 \mathrm{~cm}^{3}$ e $10 \mathrm{~cm}^{3}$, e $20 \%$ com pneumatização maior que $10 \mathrm{~cm}^{3}$.

Beltrame et al. (2003) em seu estudo, demonstraram a incidência da pneumatização do tubérculo articular do osso temporal, em 200 radiografias panorâmicas, referentes a pacientes de ambos os gêneros, e idade cronológica entre 10 e 60 anos. Os resultados foram positivos em 3,5\% dos casos analisados, com sete casos detectados, quatro para o gênero masculino $(57,2 \%)$ e três para o gênero feminino (42,8\%); com idade cronológica variando de 19 a 59 anos. Desta maneira, os autores consideraram que a pneumatização do tubérculo articular do osso temporal, não poderia ser mais considerada uma condição rara, e que seu conhecimento poderia prevenir interpretações radiográficas errôneas, e evitar acidentes em intervenções cirúrgicas na região da articulação têmporo-mandibular.

Stoopler et al. (2003) relataram o caso de uma mulher com 53 anos de idade cronológica, caucasiana, com dor orofacial, a qual apresentou na radiografia panorâmica uma extensa área radiolúcida multilocular no tubérculo articular do osso temporal, lado direito. Após o exame da tomografia computadorizada, concluíram que a imagem radiolúcida se tratava da pneumatização do tubérculo articular e que 
esta poderia causar interpretações inadequadas, pois apresentava o padrão imaginológico compatível com uma lesão.

Fontanella et al. (2003) por meio de estudo retrospectivo das séries publicadas, revelaram que em 4579 radiografias panorâmicas, a incidência da pneumatização do arco zigomático era presente em 1,7\%, não havendo predileção por gênero. Os autores apresentaram imagens, em que a radiografia panorâmica e a tomografia hipocicloidal revelaram esta variação da normalidade; salientando que os profissionais deviam ficar atentos, por simularem a presença de alguma afecção.

Panella, Freitas e Luiz (2003) advertiram em seu estudo e revisão da literatura, que o conhecimento dessa entidade era importante para uma interpretação radiográfica acurada da região anatômica em questão. Sendo que essa variação morfológica se apresentava radiograficamente como uma imagem radiolúcida uni ou multilocular, no arco zigomático ou no tubérculo articular do osso temporal.

Song et al. (2005) apresentaram dois casos de displasia fibrosa dos maxilares, tipo monostótica, ocorrendo no osso temporal. Por meio da revisão de literatura, definiram que a displasia fibrosa era uma doença de alteração de desenvolvimento, onde o tecido ósseo sadio era substituído por um tecido conjuntivo fibroso, com proliferação e maturação de fibroblastos. A displasia fibrosa dos maxilares, onde o osso temporal era o único afetado, possuía 60 casos descritos na literatura. Radiograficamente a displasia apresentava três padrões radiográficos clássicos: o padrão pagetóide, ou de vidro despolido era o mais comum; o padrão esclerótico com densidade uniforme; e o padrão cístico ou mixóide, onde uma área radiolúcida ovóide ou esférica era circundada por uma linha radiopaca de tecido ósseo denso. O diagnóstico diferencial incluía o meningioma, cisto ósseo 
aneurismático, cistos uniloculares, fibroma, fibroma ossificante, doença de Paget, osteocondroma, lesão central de células gigantes, granuloma eusinófilo, exostoses , osteoma e sarcomas.

Um estudo realizado por Orhan et al. (2005) demonstrou a incidência e as variações na pneumatização do tubérculo articular do osso temporal. As PTA foram observadas em 19 radiografias (1,88\%) de uma série de 1006 imagens panorâmicas, a idade cronológica média era de 36.6 ( \pm 21.06). Destes, 12 casos $(63.1 \%)$ ocorreram em mulheres e 7 casos (36.9\%) em homens. A pneumatização bilateral do tubérculo articular ocorreu em 7 casos (36.9\%). Os autores avaliaram 5 grandes séries de casos descritos na literatura, e compararam com os seus resultados, sendo que não houve diferença estatisticamente significante nos fatores idade, gênero, localização e incidência da pneumatização da tubérculo articular. O total de casos era de 6669, onde 115 (1,76\%) apresentavam a pneumatização do tubérculo articular, ocorrendo em intervalo etário de 7 a 90 anos, destes 50 (43,47\%) eram em homens e $65(56,53 \%)$ em mulheres. De todas as PTA encontradas, 28 casos ocorrendo bilateralmente $(24,34 \%)$.

You et al. (2006) fizeram um relato de caso de um paciente do gênero masculino, com 28 anos de idade cronológica, o qual que possuía um aumento de volume duro a palpação, indolor na região pré-auricular. Radiograficamente observaram imagem radiolúcida na região da tubérculo articular do osso temporal, de padrão difuso apresentando radiopacidades lobuladas. Os autores optaram por realizar resecção da área patológica, pois esta apresentava características similares ao osteossarcoma periosteal ou de baixo grau. Ao exame histopatológico houve o diagnóstico de displasia fibrosa monostótica. Como conclusão, os autores estabeleceram que a ocorrência desta doença no tubérculo articular do osso 
temporal era rara, e que neste caso não apresentava os padrões radiográficos clássicos.

Njock, Cartry e Faucon (2006) apresentaram o caso de um jovem menino de 15 anos de idade cronológica com o diagnóstico de cisto ósseo aneurismático, na região do osso zigomático e temporal. Essa lesão era raramente observada na região dos ossos do crânio, sendo que ocorria mais nos ossos longos e vértebras. Os sintomas mais comuns eram o de um aumento de volume, doloroso nas regiões zigomática e temporal, com perda de função. Radiograficamente, apresentava-se como um lesão radiolúcida expansiva, com presença de espículas ou septos intraósseos, lembrando ao "padrão de bolhas de sabão", com adelgaçamento ou destruição das corticais, ocasionalmente poderiam aparecer focos radiopacos em seu interior, os quais correspondiam a pequenas trabéculas de osso reacional. $\mathrm{O}$ tratamento de eleição era o de remoção cirúrgica da lesão.

Orhan, Delibasi e Orhan (2006) realizaram um estudo em um grupo de crianças, para avaliação radiográfica da PTA. A motivação para tal estudo foi a de que na literatura existente, definia-se que a pneumatização do processo mastóide estaria completa por volta dos 5 anos de idade cronológica, a pneumatização do processo zigomático da maxila não se inciava antes dos 9 anos de idade cronológica e que as células aéreas acessórias começavam seu desenvolvimento após a puberdade, por volta dos 13 anos. Entretanto não se sabia em que idade cronológica, as células aéreas presentes no tubérculo articular, iniciavam seu desenvolvimento; sendo que dois casos de pneumatização do tubérculo articular em crianças foram identificados, uma de 7 e outra de 11 anos de idade cronológica. A amostra do estudo foi composta de 1049 radiografias panorâmicas, referentes aos pacientes com idade cronológica média de 10,9 anos $( \pm 3.33)$ e intervalo etário de 4 
a 16 anos; destas $17(1,62 \%)$ possuíam PTA, sendo 8 (47,1\%) casos em meninas com idade cronológica média de 11,2 anos $( \pm 3.9)$ e intervalo etário de 7 a 16 anos; e $9(52,9 \%)$ casos em meninos com idade cronológica média de 11.3 anos $( \pm 2,54)$ e intervalo etário de 7 a 15 anos. A PTA bilateral ocorreu em 7 (41,1\%) casos. Quanto ao padrão radiográfico, 10 (41.6\%) eram uniloculares e 14 (58,3\%) multiloculares. De todos os casos, 3 ocorreram em crianças de 7 anos de idade cronológica; sendo que nesta série, $52,9 \%$ dos casos de pneumatização do tubérculo articular do osso temporal tinham idade cronológica entre 7 e 11 anos; o que levou os autores a salientarem que esta pneumatização se iniciava antes da puberdade. 


\section{PROPOSIÇÃO}

No presente trabalho nos propusemos a conhecer, por meio de levantamento epidemiológico, a incidência e os padrões radiográficos da pneumatização do tubérculo articular do osso temporal, por meio de radiografias panorâmicas, de pacientes atendidos pelo Serviço de Radiologia da Clínica de Odontologia da Faculdade de Odontologia da Universidade de São Paulo. 


\section{MATERIAL E MÉTODOS}

\subsection{Material}

O material utilizado foi composto por 3823 radiografias panorâmicas, referentes a pacientes que necessitaram desta modalidade de exame radiográfico, para a realização de tratamento odontológico, pelas diferentes atividades da Clínica de Odontologia, e cujas imagens se encontram no arquivo da Clínica Odontológica e no acervo da Disciplina de Radiologia do Departamento de Estomatologia da Faculdade de Odontologia da Universidade de São Paulo. O projeto de pesquisa foi submetido ao Comitê de Ética em Pesquisa e obteve o devido parecer de aprovação (Anexo A).

Um total de 4197 radiografias foram pesquisadas e coletadas dos arquivos, ressaltando que as mesmas foram obtidas com o mesmo aparelho.

Após uma análise qualitativa, para se determinar quais radiografias permitiam adequada observação da área a ser interpretada, 3823 radiografias panorâmicas foram selecionadas para o estudo em questão. 


\subsection{Métodos}

\subsubsection{Técnica Radiográfica}

As radiografias panorâmicas foram obtidas no aparelho de raios-X elipsopantomógrafo de modelo Panex- E, fabricado pela J. Morita Corporation Japão.

O tempo de exposição foi de 15 segundos, e foi utilizado o regime de trabalho de:

- $\quad$ miliamperagem - 7 a $10 \mathrm{~mA}$

- quilovoltagem - 70 a $90 \mathrm{kVp}$

Os filmes panorâmicos, da marca Kodak - Tipo TMG-RA1 e tamanho 15×30 cm, foram acondicionados em chassis porta-filmes plástico e flexível, contendo placas intensificadoras de velocidade média, da marca Kodak.

\subsubsection{Processamento Radiográfico}

Os filmes foram processados em processadora automática de marca Kodak e modelo MP7, com produtos químicos da mesma procedência e com tempo operacional de trabalho de 3 minutos. 


\subsubsection{Interpretação Radiográfica}

As interpretações radiográficas foram feitas em um ambiente escuro, utilizando-se de lupa e negatoscópio de luminescência uniforme, com moldura de cartolina preta (máscara), para impedir a projeção de luz, fora do campo da radiografia.

Apenas um observador, previamente treinado e especialista na área de Radiologia Odontológica e Imaginologia, interpretou as imagens. Para coletar os dados radiográficos de interesse ao trabalho, foi confeccionada uma ficha de coleta de dados com as seguintes informações: gênero e idade cronológica (vistos na identificação da radiografia), presença de pneumatização do tubérculo articular do osso temporal, com sua localização e padrão radiográfico (apêndice A).

A interpretação da pneumatização do tubérculo articular do osso temporal era realizada apenas se fosse observada uma pneumatização clara e indubitável, localizada no tubérculo articular e posterior a sutura zigomático-temporal, como uma imagem radiolúcida bem definida uni ou multilocular. 


\section{RESULTADOS}

A amostra do estudo é composta de 3823 radiografias panorâmicas de pacientes com idade cronológica média, observada na radiografia, de 43,2 anos ( \pm 23,2) com intervalo etário de 3 a 89 anos. Destes 1787 (46,74\%) são do gênero masculino e idade cronológica média de $46,3( \pm 24,1)$ anos e intervalo etário de 3 a 83 anos; e 2036 (53,25\%) são do gênero feminino e idade cronológica média de $44,1( \pm 23,4)$ anos e intervalo etário de 3 a 89 anos. (tabela 5.1 e gráfico 5.1).

Tabela 5.1 - Análise descritiva (freqüência e percentual) das características da amostra de pacientes do estudo, quanto a idade e gênero

\begin{tabular}{c|c|c|c}
\hline \multirow{2}{*}{ Gênero } & $\begin{array}{c}\text { Número de } \\
\text { Indivíduos } \\
\text { (percentual) }\end{array}$ & $\begin{array}{c}\text { Idade Cronológica } \\
\text { Média (desvio } \\
\text { padrão) }\end{array}$ & Intervalo Etário \\
\hline Masculino & $1787(46,74 \%)$ & $46,3( \pm 24,1)$ & $3-83$ \\
Feminino & $2036(53,25 \%)$ & $44,1( \pm 23,4)$ & $3-89$ \\
TOTAL & $3823(100 \%)$ & $43,2( \pm 23,2)$ & $3-89$ \\
\hline
\end{tabular}




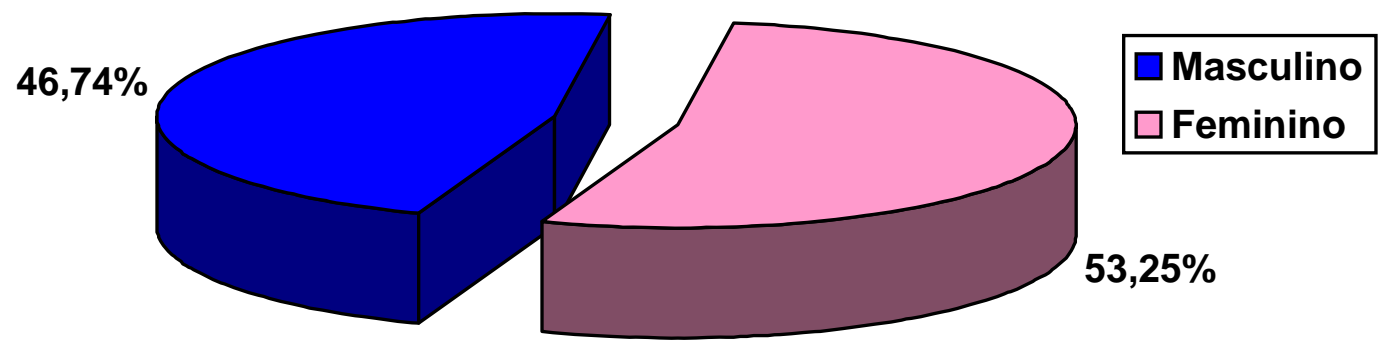

Gráfico 5.1 - Distribuição de freqüência da população do estudo, segundo gênero

A pneumatização do tubérculo articular do osso temporal foi encontrada em $68(1,78 \%)$ pacientes. Estes pacientes tinham idade cronológica média de 40 anos $( \pm 24,3)$.

Em 39 (57,4\%) casos os pacientes eram do gênero feminino com idade média de 38,92 ( $\pm 20,49)$ anos e intervalo etário de 13 a 85 anos; e em $29(42,6 \%)$ casos casos eram do gênero masculino com idade cronológica média de 41,03 $( \pm 21,63)$ anos e intervalo etário de 8 a 87 anos (tabela 5.2 e gráfico 5.2). O paciente mais jovem com pneumatização foi em um menino de 8 anos de idade cronológica. 
Tabela 5.2 - Análise descritiva (freqüência e percentual) das características da amostra de pacientes do estudo que possuíam pneumatização do tubérculo articular, quanto a idade e gênero

\begin{tabular}{c|c|c|c}
\hline \multirow{2}{*}{ Gênero } & $\begin{array}{c}\text { Número de } \\
\text { Indivíduos } \\
\text { (percentual) }\end{array}$ & $\begin{array}{c}\text { Idade Cronológica } \\
\text { Média (desvio } \\
\text { padrão) }\end{array}$ & Intervalo Etário \\
\hline Masculino & $29(42,6 \%)$ & $41,03( \pm 21,63)$ & $8-87$ \\
Feminino & $39(57,4 \%)$ & $38,92( \pm 20,49)$ & $13-85$ \\
TOTAL & $68(100 \%)$ & $40( \pm 24,3)$ & $8-87$ \\
\hline
\end{tabular}

Gráfico 5.2 - Distribuição de freqüência da população do estudo que possuía pneumatização do tubérculo articular do osso temporal, segundo gênero

Quanto a localização radiográfica, 42 (61,8\%) casos eram unilaterais, com 20 do lado direito e 22 do lado esquerdo. Casos bilaterais foram encontrados em 26 $(38,2 \%)$ pacientes (tabela 5.3 e gráfico 5.3$)$. 
Tabela 5.3 - Análise descritiva (freqüência e percentual) da pneumatização do tubérculo articular, segundo sua localização

\begin{tabular}{c|c}
\hline Localização & Número de Indivíduos (percentual) \\
\hline Unilateral & $42(61,8 \%)$ \\
Bilateral & $26(38,2 \%)$ \\
TOTAL & $68(100 \%)$ \\
\hline
\end{tabular}

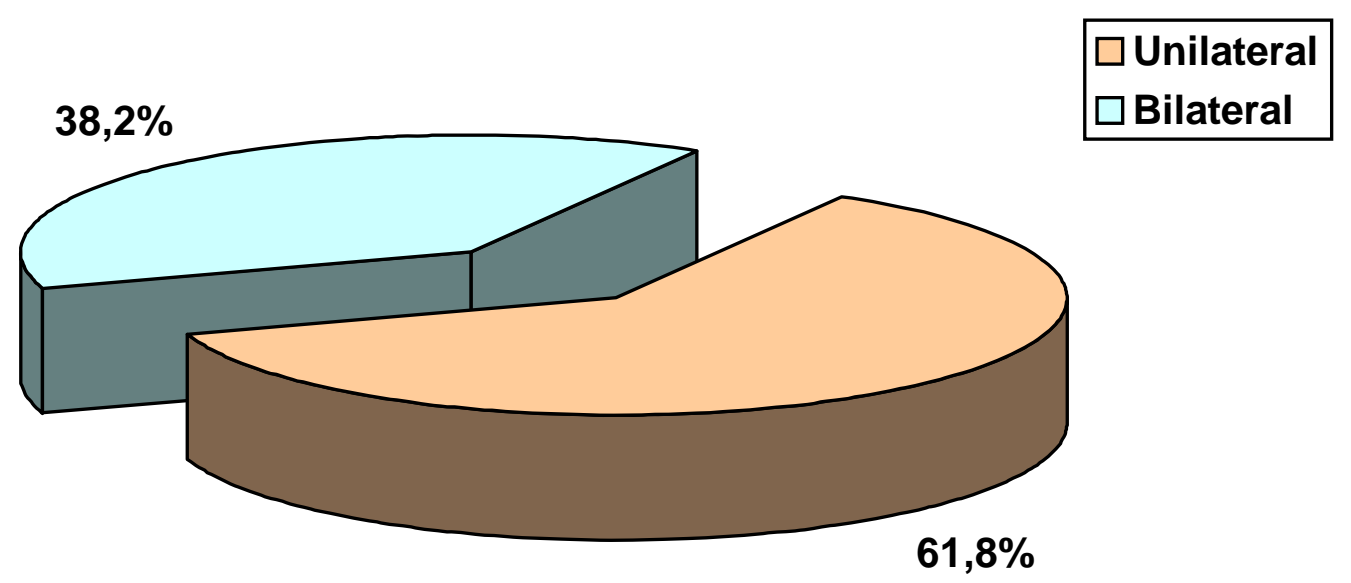

Gráfico 5.3 - Distribuição de freqüência da pneumatização do tubérculo articular, segundo sua localização

Quanto ao aspecto radiográfico, das 94 pneumatizações do tubérculo articular do osso temporal observadas, $42(44,6 \%)$ eram de padrão radiográfico unilocular e $52(55,4 \%)$ eram de padrão multilocular (tabela 5.4 e gráfico 5.4). 
Tabela 5.4 - Análise descritiva (freqüência e percentual) da pneumatização do tubérculo articular, segundo o padrão radiográfico

\begin{tabular}{c|c}
\hline Localização & Número de Indivíduos (percentual) \\
\hline Unilocular & $42(44,6 \%)$ \\
Multilocular & $52(55,4 \%)$ \\
TOTAL & $94(100 \%)$ \\
\hline
\end{tabular}

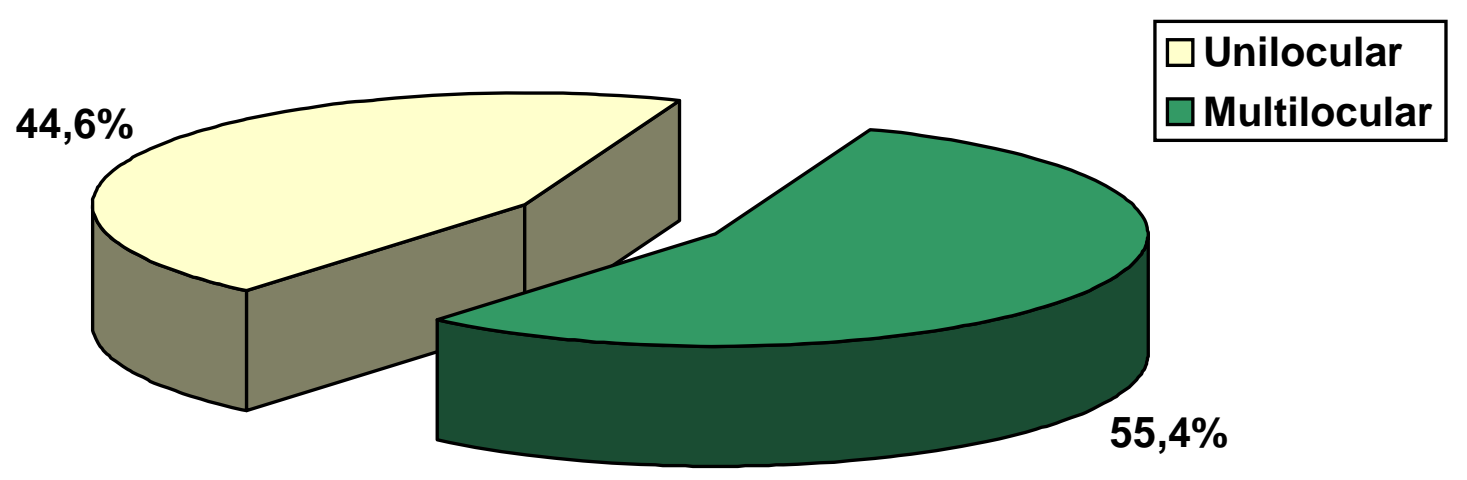

Gráfico 5.4 - Distribuição de freqüência da pneumatização do tubérculo articular, segundo seu padrão radiográfico

Amostras das imagens radiográficas panorâmicas de pacientes que possuíam PTA são apresentadas a seguir, dividas de acordo com o padrão radiográfico observado: uniloculares (figura 5.1) e multiloculares (figura 5.2). 

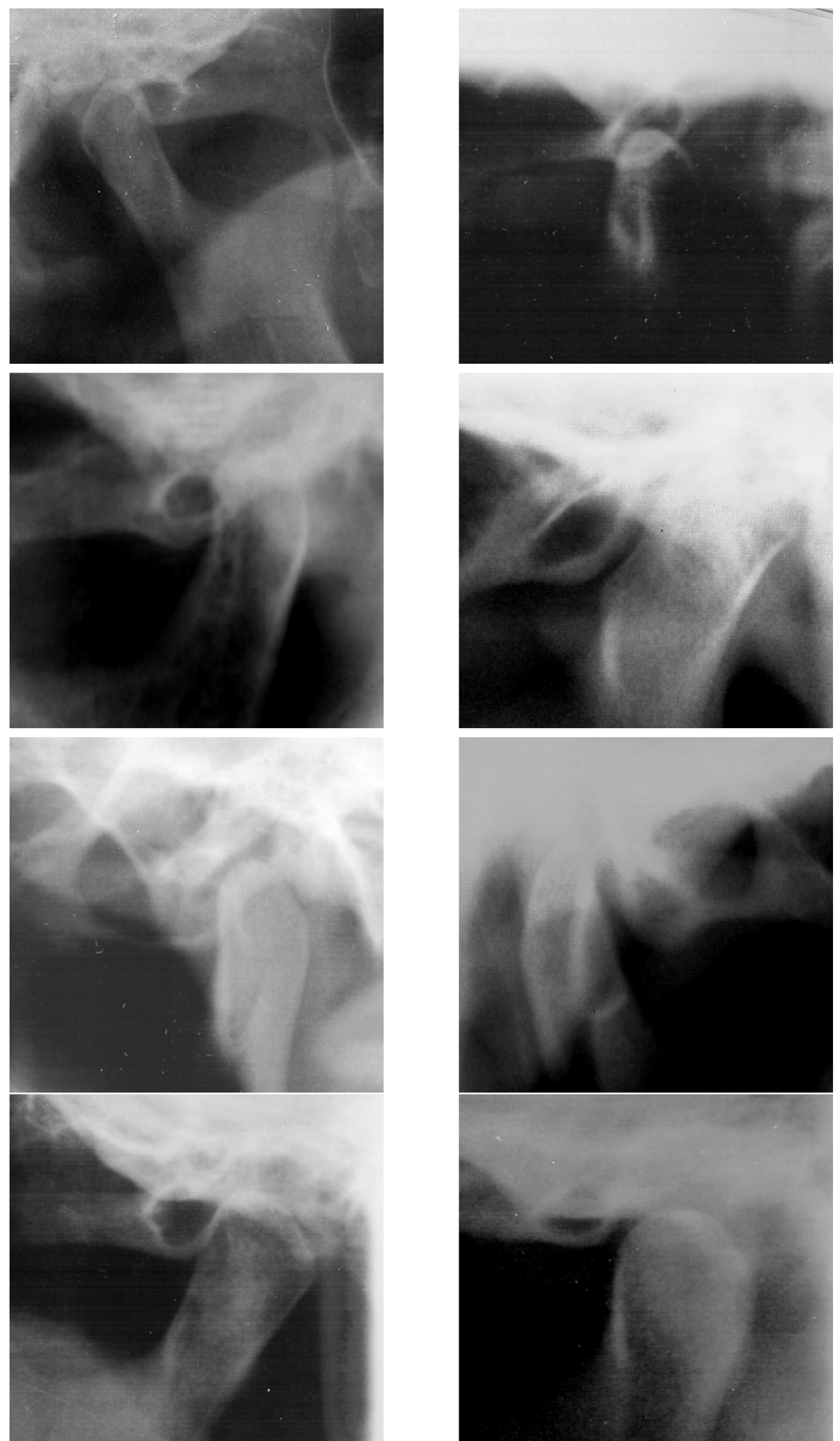

Figura 5.1 - Detalhes das articulações têmporo-mandibulares, observadas nas radiografias panorâmicas de pacientes que possuiam PTA de padrão radiográfico unilocular 

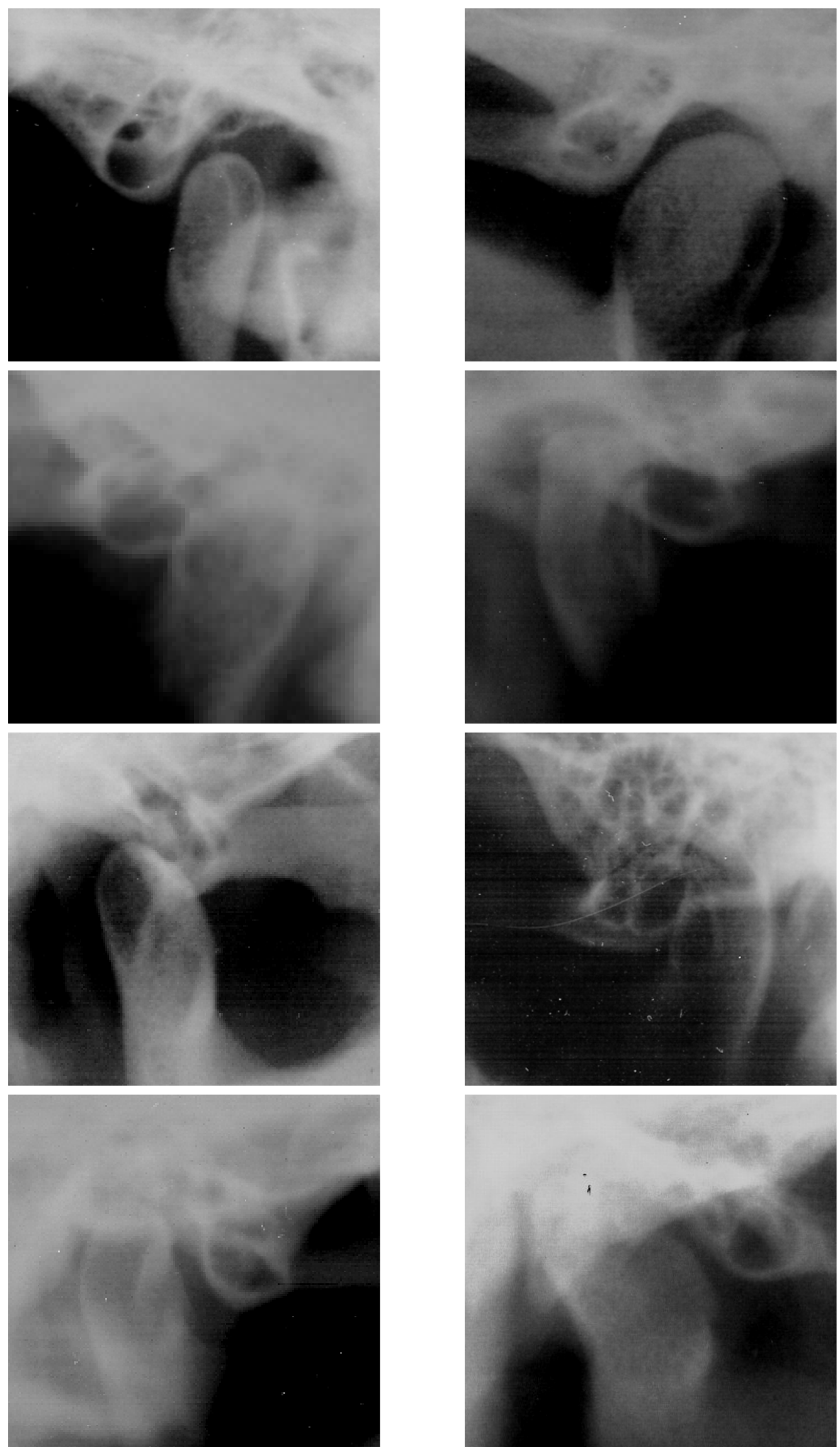

Figura 5.2 - Detalhes das articulações têmporo-mandibulares, observadas nas radiografias panorâmicas de pacientes que possuiam PTA de padrão radiográfico multilocular 


\section{DISCUSSÃO}

Anatomicamente Kowalik (1967) já havia descrito a presença de pequenas cavidades ósseas no osso temporal, principalmente no processo mastóide, com funções variadas como recepção do som, ressonância da voz, isolante térmico e acústico, reservatório aéreo, proteção contra traumas auditivos externos e diminuição do peso do crânio.

Allam (1969) descreveu que estas cavidades ósseas preenchidas por ar, tratavam-se de pneumatizações que ocorriam naturalmente nos ossos do crânio. Provenientes de uma atividade periosteal normal, as cavidades ósseas criadas eram preenchidas inicialmente por uma medula óssea primitiva, que em seu processo de diferenciação se tornava tecido conjuntivo, mesenquimal frouxo. Posteriormente, com a invaginação epitelial neste tecido conjuntivo, formava-se uma membrana mucosa, que ao evoluir e se atrofiar, resultaria em uma fina membrana de revestimento residual e aderida ao periósteo.

O desenvolvimento destas pneumatizações no osso temporal ocorreria em 5 regiões primárias: ouvido médio, perilabiríntica, ápice da porção petrosa, escamomastoídea e acessória (ALLAM, 1969; SHAPIRO, 1981).

Segundo Shapiro (1981) e Virapongse et al. (1995) o processo da pneumatização ocorreria em 3 estágios. No estágio infantil (do nascimento ao 2 anos de idade cronológica), o processo mastóide (escamomastóide) sofria crescimento gradual com as células aéreas começando a surgir no antro mastoídeo. No estágio transitório (de 2 a 5 anos de idade cronológica), o processo escamomastoídeo seguia seu crescimento com migração das células aéreas para periferia. E no 
estágio adulto, geralmente com o término da puberdade; onde devido a expansão e calcificação de suas paredes, as células aéreas ficavam mais evidentes radiograficamente e seu desenvolvimento se completaria.

Dietzel (1989) descreveu o padrão de normalidade, da pneumatização do osso temporal, por meio da mensuração das áreas radiográficas das pneumatizações, a qual seguia uma distribuição em curva normal, sendo que a principal região pneumatizada seria a do processo mastóide, do qual as pneumatizações acessórias seriam provenientes. Koc et al. (2003) descreveu o padrão por meio da medida do volume das pneumatizações, por meio da tomografia computadorizada. Confirmando o que muitos outros autores demonstraram, a grande variação no grau de pneumatização do osso temporal apresentado pela população (ALLAM, 1969; GROELL; FLEISCHMANN, 1999; LINDEMAN; HAGLUND, 1983; VIRAPONGSE et al.,1995)

Virapongse et al. (1995) afirmaram que as células aéreas periantrais, localizadas superiormente ao processo mastóide, poderiam migrar para a porção escamosa do osso temporal, podendo atingir até o arco zigomático.

O grau de pneumatizações no osso temporal influenciava negativamente a evolução de processos sépticos, como mastoidites e otites médias; bem como na cicatrização pós-cirúrgica (HOFMANN et al., 2001; KOC et al., 2003; RANDZIO et al., 1989; STRICKER, 1970), contribuindo para infecções mais complexas e refratárias (STRICKER, 1970).

O uso de técnicas radiográficas convencionais, tais como: as técnicas póstero-anterior para seios maxilares, de Towne, submento vértex e ainda a transcraniana não promoviam uma boa imagem para a verificação das pneumatizações (TYDALL; MATTERSON, 1985). 
O exame radiográfico de eleição para se verificar a presença da pneumatização do tubérculo articular do osso temporal era a radiografia panorâmica (GROELL; FLEISCHMANN, 1999; LINDEMAN; HAGLUND, 1983; PIETTE, 1986; SANDERS; FREY; MCREYNOLDS, 1978; TYDALL; MATTERSON, 1985; VIRAPONGSE et al.,1995), mas que para uma avaliação mais detalhada, apenas a tomografia computadorizada possuía a definição ou resolução necessárias (GROELL; FLEISCHMANN, 1999; KAUGARS; MERCURI; LASKIN, 1986; KOC et al., 2003; VIRAPONGSE et al.,1995).

Wong e Munk (1999) advertiram que a pneumatização excessiva do osso temporal poderia confundir, quando da realização de exames de ressonância magnética, por aparecer como uma área de hiposinal, a qual poderia ser confundida com imagens compatíveis com lesões fibrosas ou ósseas, e que nestas situações uma tomografia computadorizada seria necessária.

Muitos autores advertiram que frente a interpretação de pneumatização do tubérculo articular, o planejamento de uma intervenção cirúrgica na região têmporomandibular deveria ser criterioso para evitar acidentes transoperatórios e complicações pós-cirúrgicas (BELTRAME et al., 2003; KAUGARS; MERCURI; LASKIN, 1986; KULIKOWSKI; SCHOW; KRAUT, 1982; RANDZIO et al., 1989;)

O uso de osteótomos e cinzéis deve ser cuidadoso para evitar, perfuração da membrana dural e extravasamento de líquido cérebro-espinal, além de prever a necessidade de técnicas de reconstrução (KAUGARS; MERCURI; LASKIN, 1986)

Os primeiros relatos e muitos outros posteriormente, mostraram que a interpretação da pneumatização acessória atingindo a região do tubérculo articular do osso temporal, ocorria devido a achados radiográficos em exames de rotina (DELUKE, 1995; HASNAINI, 2000; KAUGARS; MERCURI; LASKIN, 1986; 
KULIKOWSKI; SCHOW; KRAUT, 1982; PIETTE, 1986; RANDZIO et al., 1989; ROSER; RUDIN; BRADY, 1976; SANDERS; FREY; MCREYNOLDS, 1978; STOOPLER et al., 2003; TYDALL; MATTERSON, 1987; YUROSKO, 1985;).

Piette (1986) já advertia que com o uso da radiografia panorâmica como rotina, ocorreria aumento no número de achados radiográficos deste tipo. Devido a isto, alguns trabalhos epidemiológicos a respeito da pneumatização do tubérculo articular do osso temporal foram realizados (BELTRAME et al., 2003; CARTER et al., 1999; DELUKE, 1995; FONTANELLA et al., 2003; KAUGARS; MERCURI; LASKIN, 1986; MATTERSON, 1985; ORHAN et al., 2005; ORHAN; DELILBASI; ORHAN, 2006; TYDALL; HOFMANN et al., 2001).

A pneumatização do tubérculo articular do osso temporal foi descrita por Tydall e Matterson (1987) sob o termo "zygomatic air cells defect" (ZACD), para descrever estas células aéreas acessórias no tubérculo articular do osso temporal.

A pneumatização do tubérculo articular do osso temporal devia possuir as seguintes características: 1- defeito radiolúcido assintomático no processo zigomático do osso temporal de aparência similar aos das células aéreas mastoídeas, 2- a extensão anterior do defeito atingiria até a tubérculo articular, mas não ultrapassaria a sutura zigomático-temporal, e 3- ausência de expansão óssea ou destruição da cortical. Radiograficamente possuía os padrões unilocular, como uma cavidade solitária; e os padrões multilocular e trabecular, pequenas células aéreas separadas por septos intra-ósseos, com aparência de favo de mel. (TYDALL; MATTERSON, 1987)

Existe uma unanimidade dos autores em mostrar a importância de se saber reconhecer a pneumatização do tubérculo articular do osso temporal, pois esta poderia mimetizar algumas doenças na região do osso temporal (BELTRAME et al., 
2003; CARTER et al., 1999; DELUKE, 1995; PANELLA; FREITAS; LUIZ, 2003; SEWERIN; ROSENKILDE; ANDERSEN, 1984; STOOPLER et al., 2003; TYDALL; MATTERSON, 1985,1987; VIRAPONGSE et al., 1995, WONG; MUNK, 1999)

Segundo Carter et al. (1999) apenas a pneumatização do tubérculo articular do osso temporal ocorria como uma imagem radiolúcida assintomática, não expansiva, não destrutiva, detectada em radiografias panorâmicas. Todas as outras condições no diagnóstico diferencial seriam caracterizadas pela presença de uma massa ou edema na região zigomática, freqüentemente associada a dor, assimetria facial, abaulamento ósseo, com destruição da cortical e padrões radiográficos mistos com pequenos focos ou espículas radiopacas; tais como: lesões císticas (SEWERIN; ROSENKILDE; ANDERSEN, 1984), cisto ósseo aneurismático, hemangiomas, tumores metastáticos (DELUKE, 1995; TYDALL; MATTERSON, 1985), lesão central de células gigantes, granuloma eusinófilo e displasia fibrosa (DELUKE, 1995; TYDALL; MATTERSON, 1987).

O cisto ósseo aneurismático na região da cabeça e pescoço é uma lesão rara com três casos descritos ocorrendo em osso zigomático, arco zigomático e osso temporal. Os sintomas mais comuns são aumento de volume doloroso nas regiões zigomática e temporal, com perda de função, presença radiográfica de lesão radiolúcida, expansiva, com presença de espículas ou septos no interior ("padrão de bolhas de sabão"), com adelgaçamento ou destruição das corticais, ocasionalmente podendo aparecer focos radiopacos em seu interior (NJOCK; CARTRY; FAUCON, 2006; PAGE; PETERS, 1995)

Existem 22 casos descritos na literatura de hemangioma ósseo na região zigomática, sendo considerada uma lesão rara, nenhuma na região do arco zigomático (SAVASTANO; RUSSO; DELL'AQUILA, 1997). Apresentava-se 
normalmente como um aumento de volume, duro à palpação, e dolorido na região infra-orbital, de crescimento gradual e contínuo, e deslocamento superior do globo ocular. Radiograficamente demonstrava imagem radiolúcida uni ou multilocular de padrão "favo de mel", expansiva, que freqüentemente continha múltiplas espículas ou padrão de "raios de sol" (MOORE et al., 2001; SAVASTANO; RUSSO; DELL'AQUILA, 1997), já por meio da tomografia computadorizada apresentava imagem com presença de um trabeculado ósseo irradiado e intacto, com corticais adelgaçadas (MOORE et al., 2001).

A displasia fibrosa em osso temporal era rara, quando este estava envolvido na doença, normalmente era afetado completamente (NAGER; HOLLIDAY, 1984). Segundo Song et al. (2005) havia apenas 60 casos descritos na literatura onde o osso temporal era o único acometido. You et al. (2006) apresentaram um caso ocorrendo no tubérculo articular do osso temporal.

Os sintomas mais comuns da displasia fibrosa em osso temporal eram a perda progressiva da audição, aumento de volume gradual e perda do contorno do osso temporal; e obliteração progressiva por tecido ósseo do canal auditivo externo (NAGER; HOLLIDAY, 1984). O padrão radiográfico variava de acordo com a maturação da lesão, apresentando 3 estágios: padrão pagetóide, ou de vidro despolido; o padrão esclerótico com densidade uniforme; e o padrão cístico ou mixóide, no qual uma área radiolúcida ovóide ou esférica era circundada por uma linha radiopaca de tecido ósseo compacto (SONG et al., 2005).

O granuloma eusinófilo, considerado uma variante da histiocitose $X$ envolvendo o osso temporal é uma condição rara, com 30 casos descritos na literatura, sendo que nenhum deles afetava o arco zigomático (YETISER; KARAHATAY; DEVECI, 2002). Inicialmente assintomática, a lesão evoluía de erosão 
na cortical do processo mastóide para destruição do osso e tecidos moles, com posterior erosão dos canais semicirculares e da cóclea; sendo freqüentemente confundida com doenças infeciosas ou condições neoplásicas (HADJIGEORGI et al., 1990). Radiograficamente, observa-se uma radiolucência bem delimitada, expansiva e destrutiva; presente na diploe óssea, afetando preferencialmente a tábua óssea externa (HADJIGEORGI et al., 1990; YETISER; KARAHATAY; DEVECI, 2002).

Streitmann e Sismanis (1996) encontraram 212 casos descritos de carcinomas metastáticos em osso temporal, geralmente originados de cânceres primários de mama, pulmão, faringe, rim e próstata; de ocorrência relativamente rara, freqüentemente não foram detectados por serem assintomáticos na fase inicial ou por ficarem desapercebidos por outras metástases mais debilitantes em outras partes do corpo. O aparecimento de sintomas em osso temporal costumavam ser tardios, mas em alguns casos sintomas otológicos foram detectados

A incidência da pneumatização do tubérculo articular do osso temporal foi discutida em 6 grandes séries (CARTER et al., 1999; HOFMANN et al., 2001; KAUGARS; MERCURI; LASKIN, 1986; ORHAN et al., 2005; ORHAN; DELILBASI; ORHAN, 2006; TYNDALL; MATTERSON, 1985), os quais levaram em consideração uma amostra da população em geral.

Dentre estes estudos haviam sido detectados dois casos de pneumatização do tubérculo articular do osso temporal em crianças de 7 e 11 anos (HOFFMANN et al., 2001; ORHAN et al., 2005).

Orhan, Delilbasi e Orhan (2006) avaliaram uma amostra de 1049 radiografias panorâmicas, referentes a crianças de 4 a 16 anos de idade cronológica, e determinaram que a pneumatização do tubérculo articular do osso temporal, iniciavase antes da puberdade, já que 3 casos ocorreram em crianças de 7 anos; sendo que 
nesta série, 52,9\% dos casos de pneumatização do tubérculo articular tinham idade entre 7 e 11 anos, com incidência de 17 (1,62\%) casos do total.

Em nosso estudo avaliamos 3823 radiografias panorâmicas, no qual observamos a pneumatização do tubérculo articular do osso temporal em 68 (1,78\%) pacientes com idade média de 40 anos, sendo 39 (57,4\%) em mulheres e 29(42,6\%) em homens; valores similares aos encontrados na literatura.

Quanto ao padrão radiográfico, 42 (61,8\%) casos eram unilaterais, com 20 do lado direito e 22 do lado esquerdo; e 26 (38,2\%) eram bilaterais. Das 94 pneumatizações do tubérculo articular do osso temporal observadas, 42 (44,6\%) eram de padrão unilocular e $52(55,4 \%)$ de padrão multilocular.

A meta-análise dos seis trabalhos da literatura, juntamente com nosso estudo, demonstrou similaridades para as características da população, quanto ao gênero e idade cronológica, e para a incidência da PTA; conforme observado na tabela 6.1.

As incidências da pneumatização do tubérculo articular do osso temporal observadas na literatura foram de: $2,6 \%, 1,0 \%, 1,5 \%, 1,8 \%, 1,88 \%, 1,62 \%$ respectivamente em (CARTER et al., 1999; HOFMANN et al., 2001; KAUGARS; MERCURI; LASKIN, 1986; ORHAN et al., 2005; ORHAN; DELILBASI; ORHAN, 2006; TYNDALL; MATTERSON, 1985) e em nosso estudo de 1,78\%. Sendo a média de 1,79\% de incidência da PTA em 11541 radiografias panorâmicas analisadas.

A idade cronológica média de 40 anos, observada em nosso estudo, foi similar a encontrada na literatura, onde a PTA é observada por volta da quarta década (CARTER et al., 1999; HOFMANN et al., 2001; KAUGARS; MERCURI; LASKIN, 1986). A idade cronológica média foi ligeiramente menor nos estudos de Tyndall e Matterson (1985) e Orhan et al. (2005); devido a amostra da população ser de adultos jovens. Em Orhan, Delilbasi e Orhan (2006), a média de idade 
cronológica da população com PTA foi de 10,9 anos, pois o intuito do trabalho era detectar a PTA em crianças.

O intervalo etário de 8 a 87 anos observado em nosso estudo foi parecido aos dos estudos de Hofmann et al. (2001) com 7 a 87 anos e de Orhan et al. (2005) com 11 a 90 anos. Em nosso trabalho, o paciente mais jovem a possuir a PTA tinha 8 anos de idade cronológica, ocorrendo antes da puberdade, conforme observado por Hofmann et al. (2001), Orhan et al. (2005) e Orhan, Delilbasi e Orhan (2006).

Nosso resultados demostraram conforme a literatura (CARTER et al., 1999; HOFMANN et al., 2001; ORHAN et al., 2005; ORHAN; DELILBASI; ORHAN, 2006; TYNDALL; MATTERSON, 1985) não haver aparentemente predileção por gênero, devendo-se considerar que nestes estudos, e em nossa série, havia uma tendência da amostra para o gênero feminino. A meta-análise demonstrou que os pacientes que possuíam a PTA, eram 57,5\% do gênero feminino e 42,5\% do gênero masculino.

A presença da PTA unilateralmente, pareceu ser a mais comum, foi de $61,8 \%$ em nosso estudo, comparável ao encontrado na literatura (CARTER et al., 1999; HOFMANN et al., 2001; ORHAN et al., 2005; ORHAN; DELILBASI; ORHAN, 2006; TYNDALL; MATTERSON, 1985;)

O padrão radiográfico da PTA é geralmente similar ao observado nas células aéreas do processo mastóide, ou seja, como uma imagem radiolúcida de limites definidos, não expansiva, não destrutiva (BELTRAME et al., 2003; CARTER et al., 1999; HOFMANN et al., 2001; ORHAN et al., 2005; ORHAN; DELILBASI; ORHAN, 2006; PANELLA; FREITAS; LUIZ, 2003; STOOPLER et al., 2003). A PTA pode apresentar os padrões radiográficos unilocular ou multilocular (BELTRAME et al., 2003; CARTER et al., 1999; HOFMANN et al., 2001; KAUGARS; MERCURI; 
LASKIN, 1986; ORHAN et al., 2005; ORHAN; DELILBASI; ORHAN, 2006; PANELLA; FREITAS; LUIZ, 2003; TYNDALL; MATTERSON, 1985; STOOPLER et al., 2003), mas alguns autores alegaram que tal classificação era desnecessária e de difícil definição, devido as sobreposições de imagens na radiografia panorâmica, a falta de relevância e aplicabilidade clínicas (CARTER et al., 1999; HOFMANN et al., 2001; KAUGARS; MERCURI; LASKIN, 1986).

Em nossos dados, observamos, porcentagens similares das formas uni ou multiloculares, conforme a literatura (ORHAN; DELILBASI;ORHAN, 2006 TYNDALL; MATTERSON, 1985). 
Tabela 6.1 - Meta - análise dos estudos sobre pneumatização do tubérculo articular do osso temporal

\begin{tabular}{|c|c|c|c|c|c|c|c|c|c|c|}
\hline Estudo & $\begin{array}{l}\text { Total de } \\
\text { Pacientes }\end{array}$ & PTA & $\begin{array}{c}\text { Gênero } \\
\text { Masculino }\end{array}$ & $\begin{array}{l}\text { Gênero } \\
\text { Feminino }\end{array}$ & Unilateral & Bilateral & \begin{tabular}{|c|} 
Padrão \\
radiográfico \\
Unilocular
\end{tabular} & \begin{tabular}{|c|} 
Padrão \\
radiográfico \\
Multilocular
\end{tabular} & $\begin{array}{c}\text { Idade } \\
\text { cronológica } \\
\text { média }\end{array}$ & $\begin{array}{c}\text { Intervalo } \\
\text { Etário }\end{array}$ \\
\hline $\begin{array}{l}\text { Tyndall \& } \\
\text { Matterson }\end{array}$ & 1061 & $28(2,6 \%)$ & $13(46,4 \%)$ & $15(53,6 \%)$ & $23(82,1 \%)$ & $5(17,9 \%)$ & $18(53,1 \%)$ & $15(46,9 \%)$ & 32,5 & $15-74$ \\
\hline Kaugars et al & 784 & $8(1,0 \%)$ & $1(12,5 \%)$ & $7(87,5 \%)$ & $4(50 \%)$ & $4(50 \%)$ & sd & sd & 45,9 & $32-69$ \\
\hline Carter et al & 2734 & $40(1,5 \%)$ & $20(50 \%)$ & $20(50 \%)$ & $32(80 \%)$ & $8(20 \%)$ & sd & sd & 49.6 & $17-83$ \\
\hline Hofman et al & 1084 & $20(1,8 \%)$ & $9(45 \%)$ & $11(55 \%)$ & 16(80\%) & $4(20 \%)$ & sd & sd & 43,2 & $7-87$ \\
\hline Orhan et al & 1006 & $19(1,88 \%)$ & $7(36,9 \%)$ & $12(63,1 \%)$ & $12(63,1 \%)$ & $7(36,9 \%)$ & sd & sd & 36,6 & $11-90$ \\
\hline Orhan et al & 1049 & $17(1,62 \%)$ & $9(52,9 \%)$ & $8(47,1 \%)$ & $10(58,9 \%)$ & $7(41,1 \%)$ & $10(41,6 \%)$ & $14(58,4 \%)$ & 10,9 & $7-16$ \\
\hline $\begin{array}{c}\text { Presente } \\
\text { estudo }\end{array}$ & 3823 & $68(1,78 \%)$ & $29(42,6 \%)$ & $39(57,4 \%)$ & $42(61,8 \%)$ & $26(38,2 \%)$ & $42(44,6 \%)$ & $52(55,4 \%)$ & 40 & $8-87$ \\
\hline Total & 11541 & $207(1,79 \%)$ & $88(42,5 \%)$ & $119(57,5 \%)$ & $146(70,5 \%)$ & $61(29,5 \%)$ & $70(46,3 \%)$ & $81(53,7 \%)$ & 36,9 & $7-90$ \\
\hline
\end{tabular}




\section{CONCLUSÕES}

Em nosso estudo, em relação a pneumatização do tubérculo articular do osso temporal, podemos concluir que:

7.1 É uma variação anatômica, que ocorre devido a pneumatização acessória do osso temporal, proveniente do processo mastóide.

7.2 Apresentou uma incidência de 1,78\% (68 casos), destes $57,4 \%$ ocorreram no gênero feminino e $42,6 \%$ no gênero masculino.

7.3 Quanto a localização 61,8\% ocorreram unilateralmente e 38,2\% foram bilaterais.

7.4 Quanto ao padrão radiográfico, das 94 imagens observadas, 44,6\% eram uniloculares e 55,4\% eram multiloculares.

7.5 Normalmente é detectada em exames radiográficos de rotina, constituindo-se em um achado radiográfico, principalmente em radiografias panorâmicas. 


\section{REFERÊNCIAS ${ }^{1}$}

Allam AF Pneumatization of the temporal bone. Ann Otol Rhinol Laryngol 1969;28:48-64.

Beltrame M, Oliveira AEF, Santos RM, Lopes FF, Vieira CL. Incidência da pneumatização na tubérculo articular do osso temporal em radiografias panorâmicas. JBA J Multidiscip Dor Crânio-Fac 2003;11(3):245-9.

Carter LC, Haller AD, Calamel AD, Pfaffenbach AC. Zygomatic air cell defect (ZACD). Prevalence and characteristics in a dental clinic outpatient population. Dentomaxillofac Radiol 1999;28(2):116-22.

Deluke DM. Pneumatization of the articular eminence of the temporal bone. Oral Surg Oral Med Oral Pathol Oral Radiol Endod 1995;79(1):3-4.

Dietzel K. The "normal" pneumatization of the temporal bone. HNO 1989;37(2):3947.

Fontanella V, Gegler A, Santos AF, Crestani MB. Pneumatizaçäo do arco zigomático JBA J Multidiscip Dor Crânio-Fac 2003;11(3):187-92.

Groell R, Fleischmann B. The pneumatic spaces of the temporal bone: relationship to the temporomandibular joint. Dentomaxillofac Radiol 1999;28(2):69-72.

Hasnaini M. Extensive temporal bone pneumatization: incidental finding in a patient with TMJ dysfunction. Dent Update 2000; 27(4):187-9.

Hadjigeorgi C, Pappounas C, Zarmakoujus P, Lafoyianni S. Eusinophilic granuloma of the temporal bone: radiological approach in the pediatric patient. Pediatric Radiology 1990;20(7):546-9.

Hofmann T, Friedrich RE, Wedl JS, Schmelzle R. Pneumatization of the zygomatic arch on pantomography. Mund Kiefer Gesichtschir 2001;5(3):173-9.

\footnotetext{
${ }^{1}$ De acordo com Estilo Vancouver. Abreviatura de periódicos segundo base de dados MEDLINE.
} 
Kaugars GE, Mercuri LG, Laskin DM. Pneumatization of the articular eminence of the temporal bone: prevalence, development, and surgical treatment. J Am Dent Assoc 1986;113(1):55-7.

Koc A, Ekinci G, Bilgili AM, Akpinar IN, Yakut H, Han T. Evaluation of the mastoid air cell system by high resolution computed tomography: three-dimensional multiplanar volume rendering technique. J Laryngol Otol 2003;117(8):595-8.

Kowalik S. Pneumatization of the temporal bone and the size of the maxillary fossa and articular node. Czas Stomal 1967;20(2):165-9.

Kulikowski BB, Schow SR, Kraut RA. Surgical management of a pneumatized articular eminence of the temporal bone. J Oral Maxillofac Surg 1982;40(5):311-3.

Lindeman P, Haglund M. Size of the mastoid air cell system obtained with two types of X-ray equipment. Acta Otolaryngol 1983;95(1-2):101-4.

Moore SL, Chun JK, Mitre AS, Som PM. Intraosseous hemangioma of the zygoma: Ct and Mri findings. AJNR Am J Neuroradiol 2001;22:1383-85.

Nager G, Holliday M. Fibrous dysplasia of the temporal bone. Update with case reports. Ann Otol Rhinol Laryngol 1984;93:630-3.

Njock LR, Cartry F, Faucon B. Aneurismal bone cyst of the temporal and zygomatic region. Rev Laryngol Otol Rhinol 2006;124(4):255-7.

Orhan K, Delilbasi C, Cebeci I, Paksoy C. Prevalence and variations of pneumatized articular eminence: a study fromTurkey. Oral Surg Oral Med Oral Pathol Oral Radiol Endod 2005;99(3)349-54.

Orhan K, Delilbasi C, Orhan Al. Radiographic evaluation of pneumatized articular eminence in a group of Turkish children. Dentomaxillofac Radiol 2006;35:365-70.

Page EL, Peters GE. Aneurismal bone cyst of the zygomatic arch. Head Neck 1995;17(4):358-9.

Panella J, Freitas CF, Luiz TB. Pneumatizaçäo do osso temporal e suas implicações com a articulação têmporo-mandibular. Rev da ABRO 2003;4(2):88-9. 
Piette E. Pneumatization of the anterior zygomatic tubercle of the temporal bone. Rev Stomatol Chir Maxillofac 1986;87(4):223-6.

Randzio J, Vogl T, Kellermann O, Geisemeyer W. Pneumatization of the articular eminence of the TMJ. A case report. Dtsch $Z$ Mund Kiefer Gesichtschir $1989 ; 4(13): 283-5$.

Roser SM, Rudin DE, Brady FA. Unusual bony lesion of the zygomatic arch. J Oral Med 1976;31:72-3.

Sanders B, Frey N, Mcreynolds J. Anatomical, radiographic, and clinical evaluation of temporomandibular articular eminence reduction as a treatment for recurrent dislocation and chronic subluxation. Ann Dent 1978;37:33-44.

Savastano G, Russo A, Dell'aquila A. Osseous hemangioma of the zygoma: a case report. J Oral Maxillofac Surg 1997;55(3):1352-6.

Sewerin I, Rosenkilde JI, Andersen V. Cyst-like pneumatization of the articular eminence seen in rotational panoramic radiographs. Tandlaegebladet 1984;88(18):648-50.

Shapiro R. Radiology of the normal skull. Chicago: Year book medical 1981.

Stoopler ET, Pinto A, Stanton DC, Mupparapu M, Sollecito TP. Extensive pneumatization of the temporal bone and articular eminence: na incidental finding in a patient with facial pain. Case report and review of literatura. Quintessence Int 2003;34(3):211-4.

Streimann MJ, Sismanis A. Metastatic carcinoma of the temporal bone. Am J Otol 1996;17(5):780-3.

Striker G. Pneumatization of the temporal bone and the healing process after mastoidectomy in childhood with and without antibiotics. Pract Otorhinolaryngol 1970;32(4):219-30.

Song JJ, Jung $\mathrm{HH}$, Lee HM, Hwang SJ. Monostotic fibrous dysplasia of the temporal bone: Report of two cases and review of its characteristics. Acta Oto-Laryngologica 2005;125(10):1126-9. 
Tyndall DA, Matteson SR. Radiographic appearance and population distribution of the pneumatized articular eminence of the temporal bone. J Oral Maxillofac Surg 1985;43(7):493-7.

Tyndall DA, Matteson SR. The zygomatic air cell defect (ZACD) on panoramic radiographs. Oral Surg Oral Med Oral Pathol 1987;64(3):373-6.

Virapongse C, Sarwar M, Bhimani S, Sasaki C, Shapiro R. Computed tomography of the temporal bone pneumatization: 1 Normal pattern and morphology. AJNR Am J Neuroradiol 1995;6:551-9.

Yetiser S, Karahatay S, Deveci S. Eosinophilic granuloma of the bilateral temporal bone. Int J Pediatr Otohinolaryngol 2002;62:169-73.

You YC, Jung S, Park J, Park YK, Ryu K. Monostotic fibrous dysplasia of the articular eminence of zygomatic bone. Br J Oral Maxillo Surg 2006;44(2):15-9.

Yurosko JY. Pneumatized articular eminence. Oral Surg Oral Med Oral Pathol 1985;40:311-3.

Wong K, Munk PL. Magnetic resonance imaging of the temporomandibular joint: diagnostic difficulty caused by extensive pneumatization of the mastoid air cells. Skeletal Radiol 1999;28(10):577-80. 


\begin{tabular}{|} 
Radiografia Panorâmica $\mathrm{n}^{\circ} \_$ \\
Gênero: $\square \mathrm{M} \quad \square \mathrm{F}$ \\
Idade Cronológica : $\_$m (na radiografia) \\
Interpretação Radiográfica \\
1. Pneumatização do tubérculo articular do osso Temporal \\
$\square$ SIM $\square$ NÃO \\
2. Se presente, está: \\
$\square$ Unilateral $\square$ Bilateral \\
3. Padrão Radiográfico: \\
$\square$ Unilocular $\square$ Multilocular
\end{tabular}




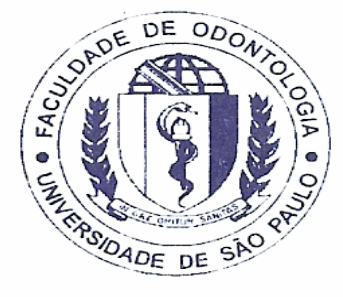

\section{UNIVERSIDADE DE SAO PAULO FACULDADE DE ODONTOLOGIA}

\section{PARECER DE APROVAÇÃO Protocolo 180/06}

O Grupo de Trabalho indicado pelo Comitê de Ética em Pesquisa APROVOU o protocolo de pesquisa "Pneumatização do tubérculo articular do osso temporal", de responsabilidade do Pesquisador Marcos Petto Nunes de Abreu, sob orientação do Professor Doutor Cláudio Fróes de Freitas.

Tendo em vista a legislação vigente, devem ser encaminhados a este Comitê relatórios anuais referentes ao andamento da pesquisa e ao término cópia do trabalho em "cd". Qualquer emenda do projeto original deve ser apresentada a este CEP para apreciação, de forma clara e sucinta, identificando a parte do protocolo a ser modificada e suas justificativas.

São Paulo, 09 de novembro de 2006

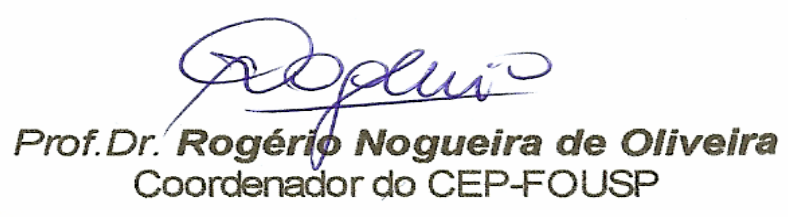

Av. Prof.Lineu Prestes, 2227 - Cidade Universitária "Armando de Salles Oliveira" CEP 05508-000 Säo Paulo - SP - Diretoria Telefax: (011)3091-0062/3091-7817/3091-7860 - Compras (011) 3091-78: 